
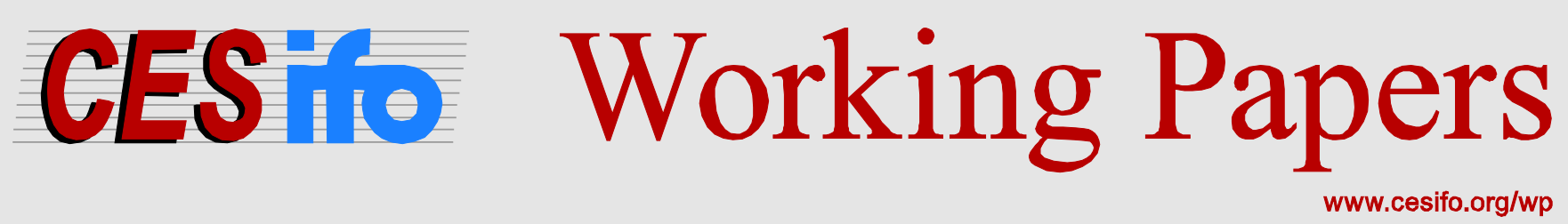

\title{
Exchange Rate Regime, Financial Market Bubbles and Long-Term Growth in China: Lessons from Japan
}

\author{
Gunther Schnabl
}

\author{
CESIFO WORKING PAPER NO. 5902 \\ CATEgory 7: MONETARY POLICY AND INTERnATIONAL FinANCE \\ MAY 2016
}

An electronic version of the paper may be downloaded

- from the SSRN website:

- from the RePEc website:

- from the CESifo website:

www.SSRN.com

www.RePEc.org

www.CESifo-group.org/wp 


\title{
Exchange Rate Regime, Financial Market Bubbles and Long-Term Growth in China: Lessons from Japan
}

\begin{abstract}
The paper argues that persistent current account surpluses and increasing foreign currencydenominated asset positions constitute long-term appreciation expectations on yuan and yen, which have made China and Japan vulnerable to U.S. interest rate cuts and appreciation expectation shocks. For both China and Japan - at different points of time - self-fulfilling runs into yuan and yen have triggered monetary policy expansions, which are identified as the breeding ground for overinvestment, speculative bubbles and post-bubble secular stagnation. To prevent a similar scenario for China capital controls, a tighter monetary policy and a fixed exchange rate regime are recommended.
\end{abstract}

JEL-Codes: E320, E420, E580.

Keywords: China, Japan, exchange rate policy, bubble economy, overinvestment, Hayek low interest rate policy, secular stagnation, capital controls, rebalancing.

\author{
Gunther Schnabl \\ Leipzig University \\ Institute for Economic Policy \\ Grimmaische Str. 12 \\ Germany - 04109 Leipzig \\ schnabl@wifa.uni-leipzig.de
}

Draft 17. March 2016.

I thank Taiki Murai for excellent research assistance. 


\section{Introduction}

Since 2015 economic growth in China is stumbling. Harshly declining stock prices, accelerating capital outflows and a depreciating currency signal vanishing confidence in the Chinese economic miracle. The Peoples Bank of China has moved towards more exchange rate flexibility and repetitive monetary expansion to forestall a hard landing of the Chinese economy. Given expected monetary tightening in the U.S. and further monetary expansion in Japan, China is faced with the question about the adequate policy response to a slow-down in the economic catch-up process.

Japan is an important case study for China for several reasons. Although Japan has started the economic catch-up process earlier and has achieved a more advanced stage of economic development (including highly developed capital markets) it shares with China several important macroeconomic characteristics: A persistent current account surplus, large and further growing foreign currency-denominated assets and recurring appreciation pressure. Furthermore, as will be argued, both countries seem to have gone through an overinvestment cycle, which - after the economic turn-around - constitutes a particular challenge for economic policy making.

Previous research has discussed in detail the determinants of Chinese growth from different angles (see for instance Huang and Rozelle 1996, Blanchard and Giavazzi 2006, Wang and $\mathrm{Hu}$ 2007). In this context, the choice of exchange rate regime has played an important role (see for instance Huang and Wang 2004, Frankel 2006, Yoshino, Kaji and Asonuma 2014). Furthermore, the reasons for the Japanese bubble economy (Bayoumi and Collyns 2000, Friedman 2000, Schnabl 2015) and the adequate policy response to the post-bubble stagnation have been widely discussed (Bernanke 2000, Posen 2000, Caballero, Hoshi and Kashyab 2008, Peek and Rosengren 2010).

However, papers comparing China and Japan, in particular with respect to the challenges of a post-bubble balance sheet recession, are rare. Fukumoto and Muto (2012) compare the rebalancing of the Chinese economy with the Japanese experience with a focus on factor inputs. McKinnon and Schnabl (2006) compare the role of the exchange rate regime in China and Japan for growth in the context of the economic catch-up process with a focus on adjustment in asset and labor markets. Schnabl (2015) compares the role of exchange rate 
policy and monetary policy for boom and bust in financial markets in Japan and Europe to derive long-term implications for growth. Yet, up to the present, the emergence of bubbles in financial markets has not been analyzed in the context of the exchange rate regime for China and Japan. This is done here to derive a policy recommendation for China with respect to the most recent economic challenges.

\section{Current Account Surpluses, Exchange Rate Strategies and Economic Conflict}

The catch-up processes of China and Japan have been orientated towards the prosperous markets of the industrialized economies (export-led growth). Both China and Japan were successful in building up trade surpluses versus the U.S. (and other industrialized countries), which became the breeding ground for economic conflict. The trade conflicts of U.S. with Japan and China comprised both disputes about specific industries (e.g. automobiles in the case of Japan, e.g. steel and solar panels in the case of China) as well as about the exchange rates of yen and yuan against the dollar. Exchange rate conflicts of the U.S. with both China and Japan emerged despite the fact that the two countries pursed different exchange rate strategies.

\subsection{Exchange Rate Policies, Current Account Surpluses and Foreign Currency- Denominated Assets in China and Japan}

With the breakdown of the Bretton-Woods-System in the early 1970s the Japanese yen had become one of the poles of the so-called tri-polar international monetary system: the yen was freely floating against the German mark and the U.S. dollar. ${ }^{2}$ The floating exchange rate of the Japanese yen against the dollar became a source of economic conflict with the United States (and other trading partners) in the early 1980s. The interest rate increase of the Federal Reserve System under Paul Volcker, which aimed to put an end to the high inflation and low growth period of the 1970s, triggered growing net capital inflows from Japan. The outcome

2 While in Europe, gradually, the German mark assumed the role of the leading international currency, with increasingly serving as an anchor for exchange rate stabilization of other European countries, an independent monetary integration process did not materialize in East Asia. Despite the end of the gold convertibility of the dollar most smaller East Asian countries kept their currencies pegged to the dollar, thereby constituting an informal Bretton-Woods-System II (Dooley, Folkerts-Landau and Garber 2004): Given export-oriented growth strategies and the large size of the U.S. market, exchange rate stability against the dollar remained a core element of Emerging Asia's industrialization strategies. An informal East Asia dollar standard was constituted by pegging their currencies commonly to the dollar. This reduced not only transaction costs for trade with the U.S., also intra-regional exchange rates were stabilized (McKinnon and Schnabl 2004). China joined the informal dollar standard in 1994. The floating yen remained an important outlier. 
was a strong dollar appreciation (yen depreciation), which was accompanied by the emergence of the U.S.-Japanese trade imbalance (see Figure 1). By the mid 1980s the U.S. current account deficit had grown to about $2.7 \%$ of GDP, whereas the Japanese current account surplus had grown to $3.6 \%$ of Japanese GDP.

\section{Figure 1: Current Account Balances of China, Japan and U.S.}

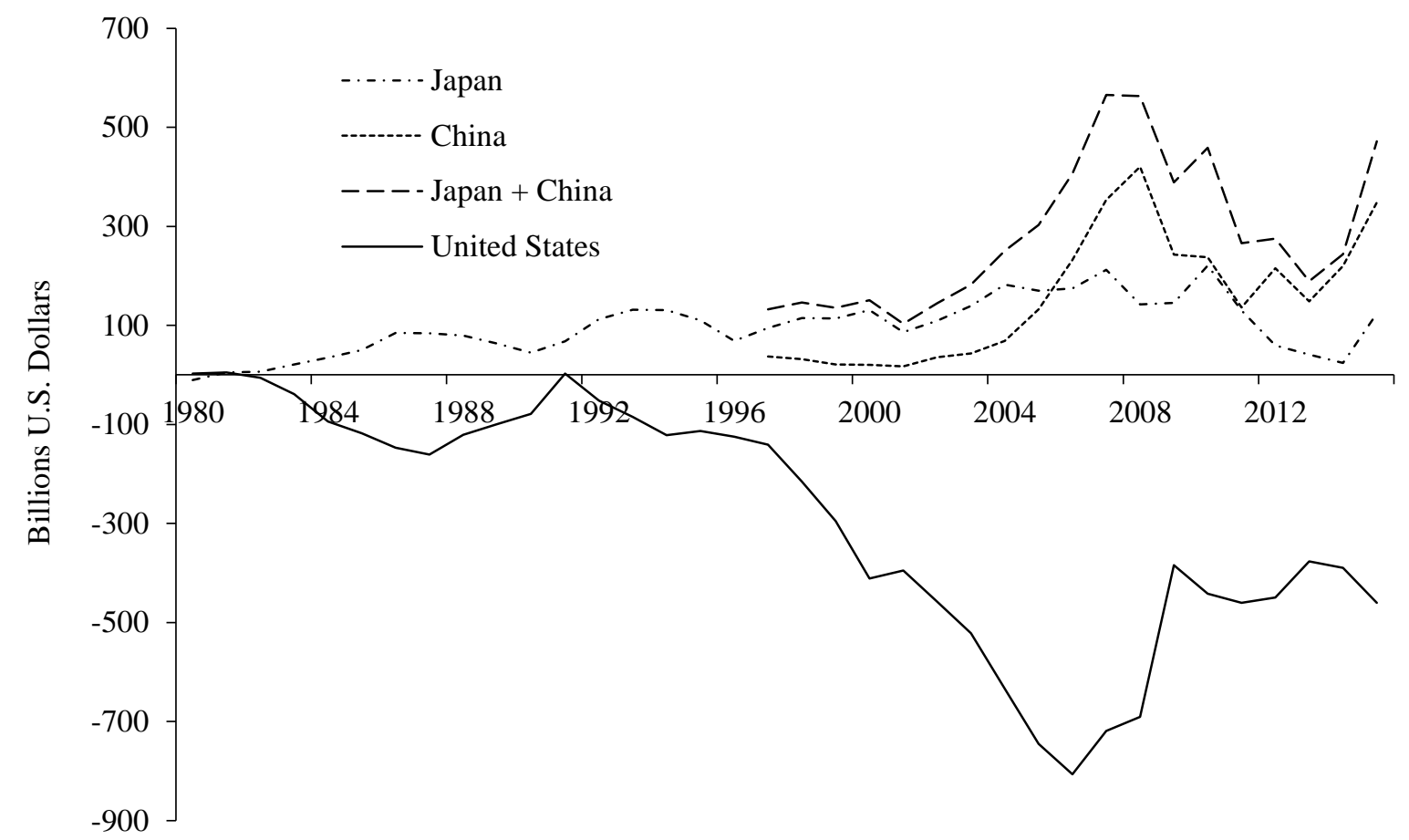

Source: IMF World Economic Outlook.

Because the sharp increase of Japanese goods imports to the U.S. was understood as a threat for employment in the U.S. manufacturing sector, Japan got under growing criticism of pursuing a mercantilist trade strategy (Japan bashing, McKinnon and Ohno 1997). The yen/dollar exchange rate became the bone of contention of a controversial discussion about the appropriate way to reduce the U.S.-Japanese trade imbalance. The September 1985 PlazaAgreement aimed to cure the trade imbalance by yen appreciation, whereas the February 1987 Louvre Accord sought to address the problem by expansionary fiscal and monetary policy in Japan (Funabashi 1989).

Despite both policy interventions the Japanese current account surplus persists up to the present (Figure 1) and contributed to an ever-growing net foreign asset position of Japan (see Figure 2), 
which reached - for the time being - its peak at 3.5 trillion dollars in 2012. ${ }^{3}$ With the Japanese yen failing to challenge the role of the dollar as the leading international currency, the largest share of Japanese foreign assets remained denominated in foreign currency, in particular U.S. dollars. $^{4}$

\section{Figure 2: Net Foreign Asset Positions of China and Japan}

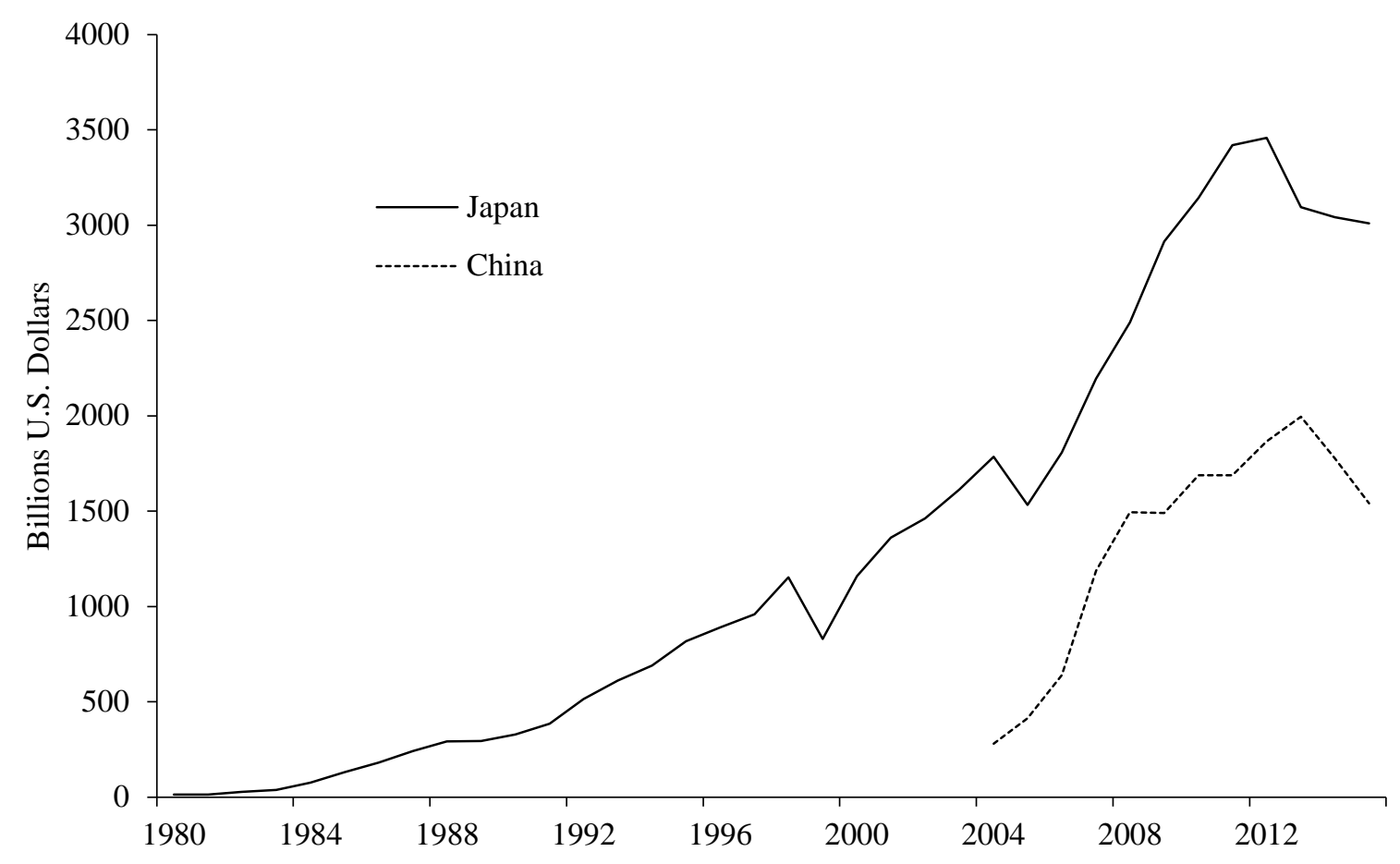

Source: IMF International Financial Statistics.

In 1994, the Chinese authorities abolished exchange controls on current-account transactions (exporting, importing, interest and dividends) and unified the exchange rate to formally satisfy the International Monetary Fund's Article VIII on current account convertibility. In contrast to Japan China pursued a tight peg to the dollar with monetary authorities allowing only for temporary and partial exchange rate flexibility. By 1995, the nominal exchange rate had settled down to about 8.28 yuan per dollar ${ }^{5}$ and was held there for 10 years (Figure 3). By providing macroeconomic stability the policy of pegging the yuan to the dollar contributed to the outstanding export and growth performance of the Chinese economy (McKinnon and Schnabl 2009).

3 As the current account positions of Japan remained positive in all years since 1981, declining net foreign assets have to be due to revaluation effects, for instance via fluctuations of the dollar against third investment currencies.

4 As reported by the Bank of International Settlements, by 2015 56.5\% of Japanese private cross-border claims were in U.S.-dollars, $12.1 \%$ in euros and $18.5 \%$ in Japanese yen (12.9\% others).

5 The exchange rate was fixed at 8.28 yuan per dollar within a narrow daily band of $\pm 0.3 \%$ until 21 July 2005 . 
In the early years of the new millennium the political economy of the Chinese dollar peg changed for two reasons. First, in response to the bursting of the dotcom bubble, the U.S. Fed strongly cut interest rates, what brought the yuan (and many other currencies at the periphery of the world dollar standard) under appreciation pressure. Second, the Chinese current account surplus started to surge, from 1.3\% of GDP in 2001 to roughly 10\% of GDP in 2007 (Figure 1). This caused complaints that China pursued a mercantilist trade strategy, damaging the U.S. manufacturing sector (see for instance Cline and Williamson 2009 and Bergsten 2009). U.S. pressure on China to allow for an appreciation of the yuan to remedy the trade imbalance intensified. Like previously in the case of Japan, the U.S. government threatened to sanction China by imposing import tariffs unless it appreciated the yuan. „China bashing“ succeeded „Japan bashing“.

\section{Figure 3: Yen and Yuan Exchange Rates against the Dollar 1980-2015}

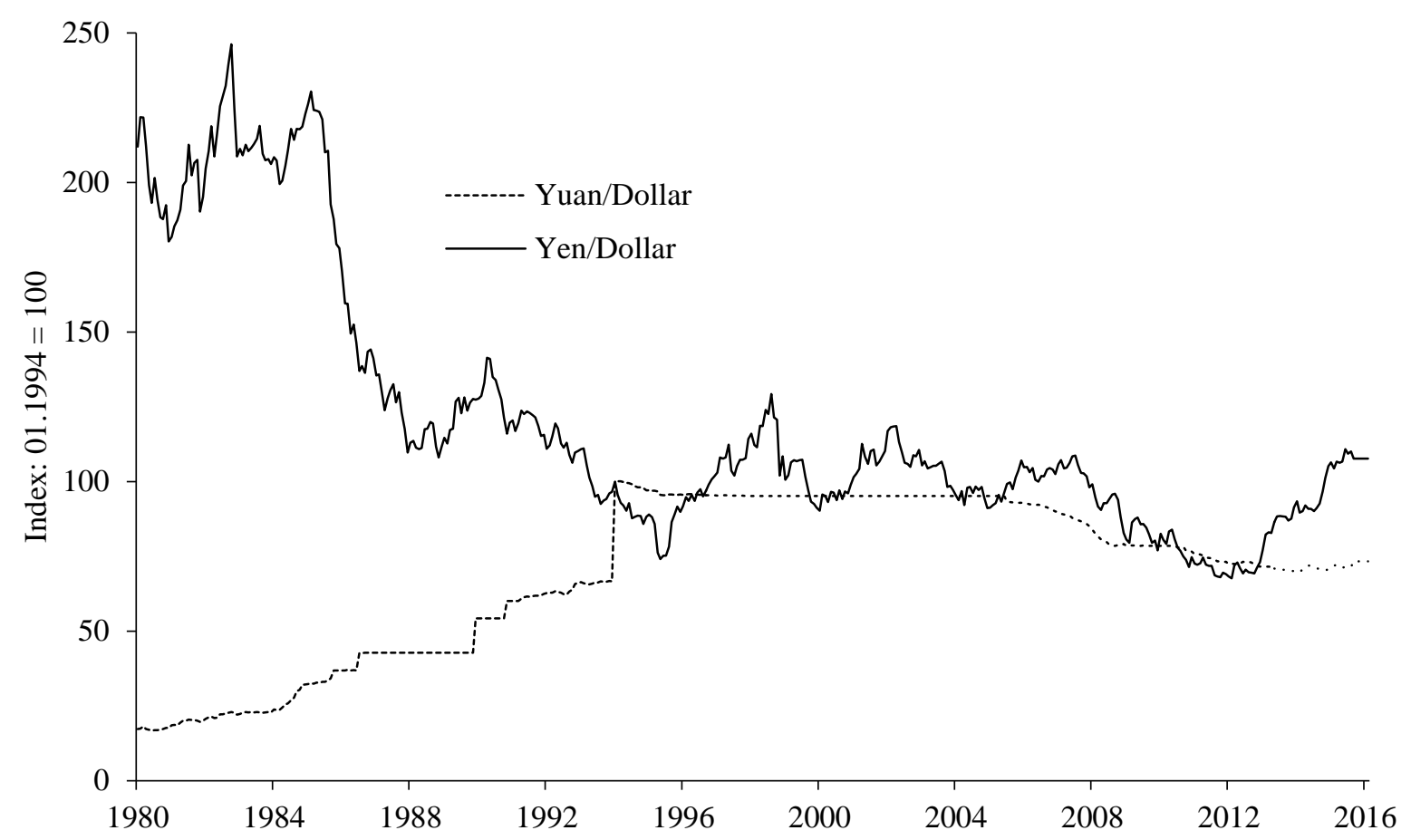

Source: IMF International Financial Statistics.

Despite a gradual nominal appreciation of the Chinese yuan against the dollar since July 2005 (Figure 3), the Chinese current account surplus persisted and the net international investment position continued to grow (Figure 2). By 2013 China’s net international investment position had risen to close to 2 trillion dollars. As in the case of Japan the largest share of the Chinese 
foreign assets was denominated in foreign currency, in particular U.S. dollars. In contrast to Japan, the main share of foreign assets was public, i.e. foreign reserves.

\subsection{Conflicted Virtue and Self-Sustained Appreciation Expectations}

The large foreign currency-denominated assets of China and Japan constitute a phenomenon, which McKinnon and Schnabl (2004) dubbed 'conflicted virtue'. Countries which are virtuous in the sense that they have large savings surpluses over investment (i.e. current account surpluses) get inflicted by trade and exchange rate conflicts. The natural currency habitat of domestic nationals - households, enterprises and financial institutions - is in their national currency. Both in China and Japan, wages and claims on financial institutions (e.g. banks and insurance companies) are in national currency (i.e. yuan and yen). This implies, that foreign currency-denominated assets are only held, if a higher return is expected.

The downside of holding dollar assets from a Japanese or Chinese investors' view is the exchange rate risk. Because the Chinese yuan is not fully convertible, Chinese financial markets are underdeveloped and controls for international capital transactions persist, the yuan cannot become a full-fledged international currency (McKinnon and Schnabl 2014). Therefore, China is not able to internationally borrow and lend in domestic currency. Similarly, although Japanese financial markets were widely liberalized in the 1970s and have become highly developed, the Japanese yen never challenged the dollar as an international currency, because international capital markets have been pre-empted by the dollar. ${ }^{6}$

With the passage of time, two things happen. Firstly, with the stock of dollar claims growing, domestic holders of dollar assets are increasingly concerned about a possible appreciation of the domestic currency. Secondly, foreigners complain about persistent current account surpluses that are regarded as "unfair" because of an "undervalued" currency. Both factors interact. The larger are the foreign assets and the external political pressure to appreciate the domestic currency, the larger are the concerns that appreciation will occur.

Self-sustaining runs into the periphery currency can be triggered, because any unanticipated appreciation would cause a loss in the foreign-currency denominated portfolio in terms of domestic currency. Depending on how sensitive Chinese and Japanese holders of dollar assets are to foreign exchange risk, runs from dollars into yen and yuan can occur. Speculators can

6 On the impeded evolvement of the international role of the yen see Taguchi (1994). 
bet on the appreciation of yuan or yen to realize speculation profits. A third factor strengthening appreciation expectations on yen and yuan has been the gradual monetary expansion in the United States. Any move of the core country in the international monetary system towards monetary expansion led to additional appreciation pressure on the periphery currencies. In particular, since the turn of the millennium and since 2007, the Federal Reserves' low interest rate decisions and several rounds of quantitative easing created a growing incentive to convert dollars into other currencies.

In Japan the built up of foreign-currency denominated assets was mainly driven by private capital outflows, with foreign reserve accumulation substituting private foreign assets only discretionally. ${ }^{7}$ With short-term and long-term interest rates remaining constantly below U.S. interest rates, Japanese investors could realize higher returns from investment in the U.S. (see Figure 4). ${ }^{8}$ In contrast, in China due to capital controls the interest rate could remain higher than in the U.S. (see Figure 4). Given a fixed exchange rate to the dollar and since 2005 recurring appreciation expectations, this implied an incentive to hold yuan rather than dollar assets. Therefore, from 2001 to 2014 China experienced large private capital inflows. The Peoples Bank of China intermediated the current account surpluses, the inflows of illiquid claims (FDI) ${ }^{9}$ and speculative capital inflows by buying large amounts of foreign reserves to ensure the international portfolio balance equilibrium. The resulting build-up of foreign reserves is shown in Figure 5.

Both in Japan and China events occurred that triggered self-sustaining runs into yen and yuan. With the September 1985 Plaza-Agreement a substantial appreciation of the Japanese yen against the U.S. dollar was announced and underpinned by a monetary tightening in Japan (Funabashi 1989). ${ }^{10}$ The public announcement of yen appreciation by the five leading industrial countries opened the door for one-way bets on yen appreciation and therefore hardly containable speculative capital inflows (McKinnon and Ohno 1997). Between

See Takagi (2015) on the discretionary nature of Japanese foreign exchange intervention. Japanese foreign reserve accumulation was comparatively large until 2004 and mainly abated since then (see Figure 5). This can be attributed to the emergence of the upward crawling peg in China, which took appreciation pressure from the yen and therefore reduced the need for foreign exchange intervention in Japan.

8 Given that the uncovered interest rate parity holds the appreciation of the yen against the dollar is equal to the interest rate differential between Japan and the U.S.. From a long-term perspective the uncovered interest rate parity is not fully fulfilled for Japan and the U.S.. Concerning a negative risk premium on the Japanese interest rate originating in exchange rate uncertainty see Goyal and McKinnon (2003).

9 In contrast to Japan, since the start of its economic catch-up process China has been an important recipient of foreign direct investment (FDI). Whereas in Japan net FDI outflows contributed to the financing of the current account surplus, in China huge net FDI inflows necessitated additional foreign reserve accumulation.

10 The rational of the Plaza-Agreement followed the elasticity approach to international trade (as e.g. in Meade 1951), which assumes that an appreciation slows down exports and stimulates imports thereby reducing a trade surplus. 
September 1985 and September 1987 the yen appreciated by more than 50\% against the dollar (Figure 3), far beyond the originally intended target.

Figure 4: Short-term and Long-term Interest Rates, Japan-U.S. and China-U.S.

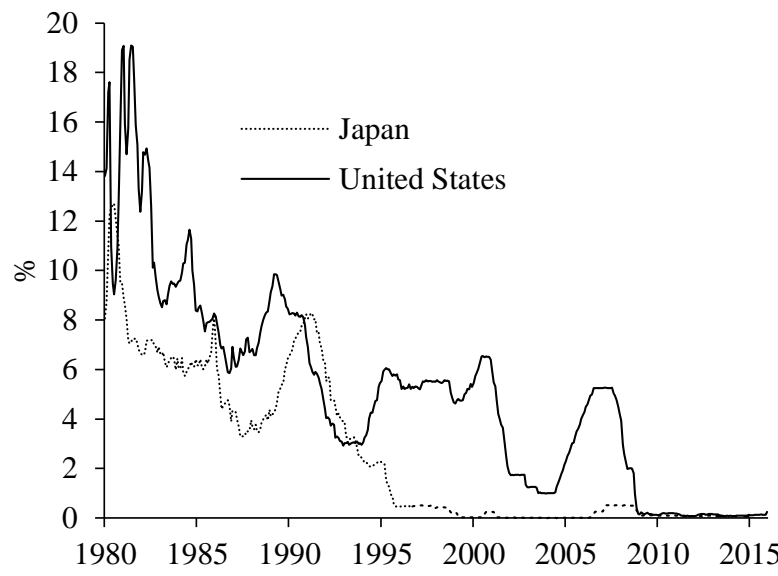

short-term

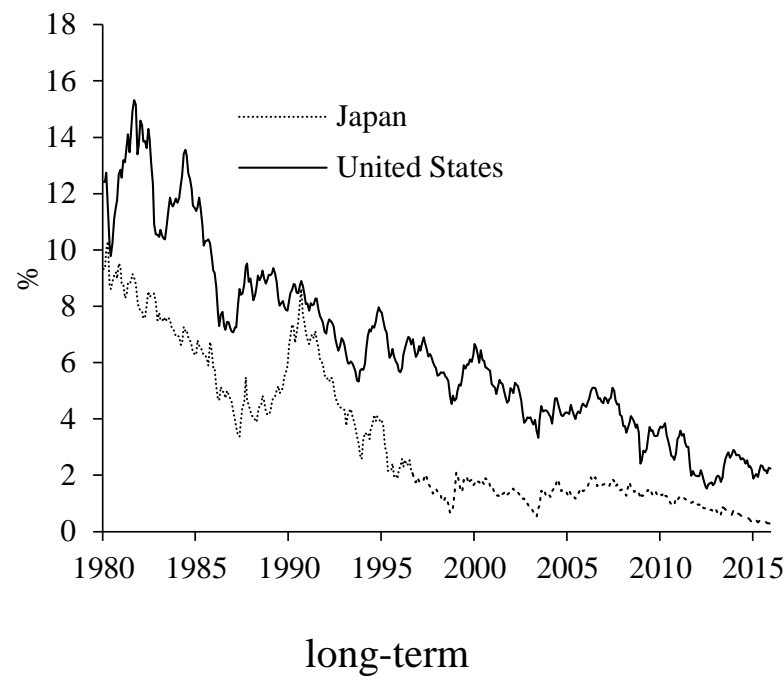

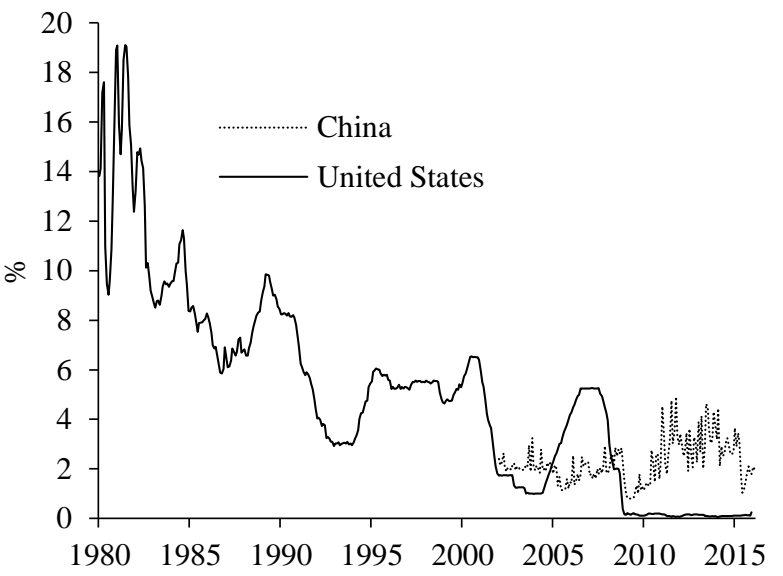

short-term

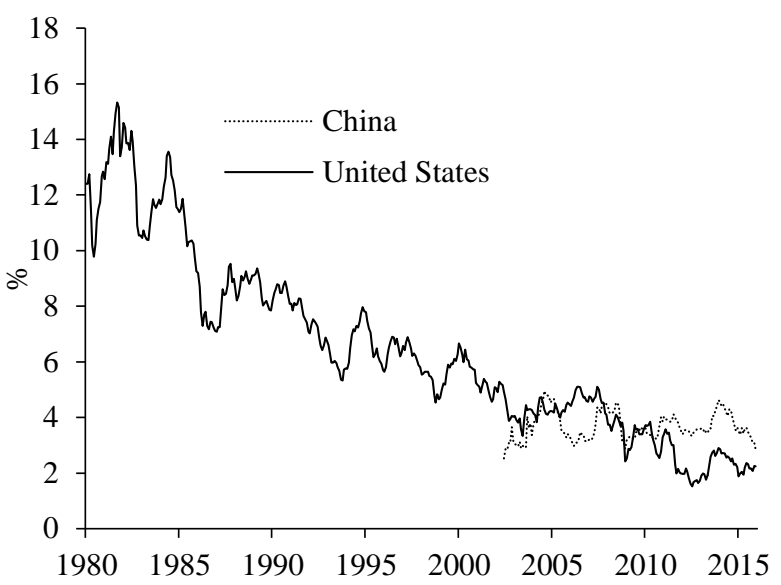

long-term

Source: IMF International Financial Statistics, The People’s Bank of China, Thomson Reuters Datastream.

With the Plaza Agreement failing, ${ }^{11}$ the U.S. pressure on Japan to appreciate the yen in the context of trade conflicts continued until mid 1995: When, concerned about the slumping

11 The post-Plaza yen appreciation failed to correct the trade imbalance for mainly three reasons. Firstly, Japanese export enterprises cut export prices in yen because they priced their products in dollars to the U.S. market (Athukorola and Menon 1994). Secondly, to the extend that the yen appreciation was shifted to dollar prices, Japanese exports declined, causing a deep recession in Japan. The negative growth effect made also imports decline, leaving the exchange rate effect on the trade balance indeterminate (McKinnon and Ohno 1997). Thirdly, as the appreciation took a persistent nature, profit margins were adjusted by increasing productivity and cutting wage costs (Mann 1986). Therefore, fundamentals adjusted to the relative price of yen and dollar in the foreign exchange market: Gradually the wholesale price and consumer price-based purchasing power parity converged to the appreciated nominal yen/dollar rate. 
Japanese economy, the U.S. Treasury Secretary, Robert Rubin announced a new "strong dollar" policy and U.S. interest rates were increased (Figure 4), Japan bashing more or less ceased (McKinnon and Schnabl 2006). Nevertheless, given the continuing structural decline of U.S. interest rates, the appreciation pressure on the yen persisted. Only, when under the umbrella of the Abenomics the Bank of Japan moved towards drastic monetary expansion starting from 2013, the yen depreciated substantially against the dollar (see Figure 3).

Self-sustaining appreciation expectations on the yuan were triggered, when on July 21 2005, China gave in to U.S. pressure to let appreciate the yuan. The Chinese currency was appreciated discretely by 2.5 percent. Subsequently, the Peoples Bank of China established a gradual appreciation path of the yuan versus the dollar by about 3 to 6 percent per year up to July 2008 (upward crawling peg) (Figure 3). Given that investors could easily anticipate an appreciation of the yuan against the dollar, they could make significant revaluation gains, if they could find their way around the inward-bound capital controls. ${ }^{12}$

Therefore, speculative capital inflows and foreign reserve accumulation in China accelerated since 2005 (Figure 5). Given inward-bound capital controls the speculative capital inflows tended to be disguised as export earnings, which were allowed to be repatriated. ${ }^{13}$ This implies that a substantial part of the speculative capital inflows showed up as rising exports, what explains the hike in the current account surplus up to the year 2007 (see Figure 1).

Between July 2008 and June 2010 the gradual appreciation path was interrupted during the global financial crisis and the yuan was tightly re-pegged to the dollar at 6.83 yuan per dollar. With China moving towards a multi-trillion dollar fiscal expansion lasting through 2010, this ensured the effectiveness of the fiscal stabilization program. ${ }^{14}$ In July 2010 the appreciation path was resumed and continued until the year 2014, when expectations turned towards yuan depreciation. The reversal of capital flows is reflected in a substantial decline in the Peoples Bank of China's foreign reserve holdings (Figure 5).

\footnotetext{
12 During the time, when die Peoples Bank of China signalled a predictable appreciation of the yuan, for instance Chinese export enterprises and real estate developers could make easy money by issuing dollar bonds at low interest rates (e.g. at 1\%), convert the receipts into yuan and invest it in China (e.g. at an 5\% return). Given a predictable appreciation of the yuan of e.g. 3\% per year, the net return was $7 \%$.

13 See Cheung, Steinkamp and Westermann (2016).

14 In the seminal Mundell-Fleming model (Mundell 1963) an expansionary fiscal policy in a flexible exchange rate regime is ineffective, as the fiscal stimulus is counteracted by interest rate increases and appreciation of the domestic currency.
} 
Figure 5: Foreign Reserves of China and Japan 1980-2015

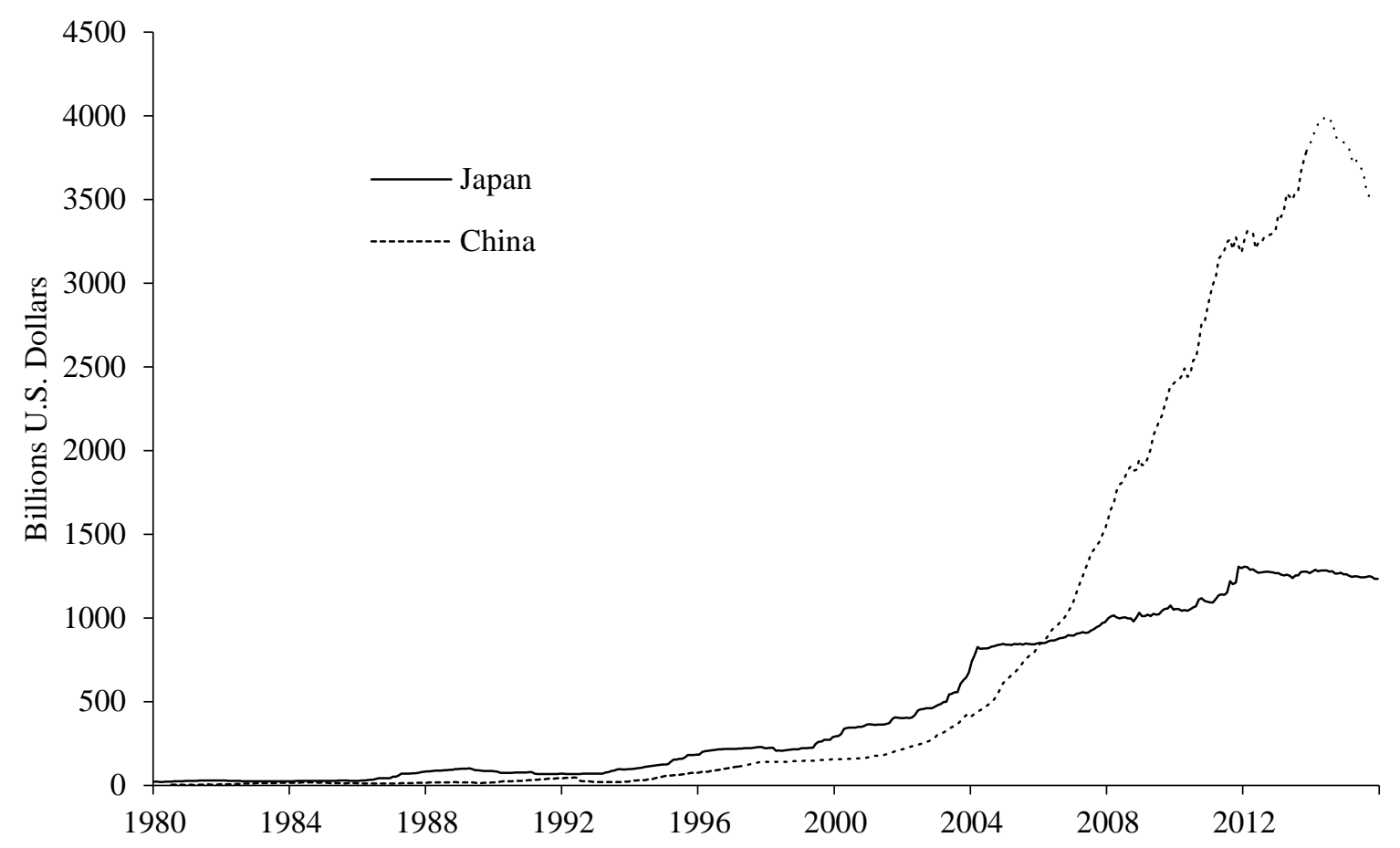

Source: IMF International Financial Statistics.

\section{Financial Market Implications of Appreciation Expectation Shocks}

Foreign exchange markets and financial markets interact. If central banks buy foreign currency from commercial banks to weaken the exchange rate of the domestic currency, they remunerate the foreign currency purchases by increasing the current account balances of commercial banks at the central bank. If the foreign exchange purchases remain unsterilized or if sterilized foreign exchange intervention is followed by interest rate cuts ${ }^{15}$, the monetary base increases. The resulting decline in interest rates affects the international portfolio allocation of domestic and foreign investors, what strengthens the effect of the foreign currency purchases on exchange rates via capital outflows. If foreign exchange intervention is fully sterilized the effect on the exchange rate is uncertain. If, however, (partial) sterilization is combined with capital controls, portfolio allocation on domestic financial markets can be affected again.

15 This corresponds to the so-called signalling effect of foreign exchange intervention (see Mussa 1981): The sterilized foreign exchange intervention signals a change in the monetary policy stance, which corresponds to unsterilized intervention. 


\subsection{Overinvestment and Financial Market Bubble in Japan}

The Japanese bubble economy, which emerged following the Plaza Agreement can be explained theoretically based on the monetary overinvestment theories of Wicksell (1898), Mises (1912) and Hayek (1929): ${ }^{16}$ If the interest rate is set by the central bank below a socalled natural interest rate, which represents an equilibrium between savings and investments, an unsustainable credit-driven investment boom is triggered. ${ }^{17} \mathrm{~A}$ rise in credit to the private sector at constant interest rates signals falsely that saving activity of households and thereby future consumption have increased. Additional investment projects of some enterprises trigger additional investments of other enterprises. A cumulative upward process is constituted, which positively affects profits.

Spill-overs to financial markets may arise. Increasing expected profits of enterprises and banks encourage rising stock prices. Also, given relatively low interest rates on saving deposits, stock purchases become more attractive. When stock prices move upward, speculation dynamics may gain momentum such that "the symptoms of prosperity themselves finally become [...] a factor of prosperity" (Schumpeter 1912: 226). Consumption is fuelled by rising stock prices via the wealth channel, which leads, with a lag, to increasing prices, when idle capacities become fully used. As wages increase, enterprises lift prices. The pickup of inflation finally forces the central bank to lift interest rates, what increases the benchmark for the profitability of past and future investment projects. The boom turns into bust: Low-yield investment projects have to be dismantled and a cumulative downward process sets in.

The main transmission channel of monetary policy to overinvestment and/or financial market exuberance is credit provided by the commercial banks to the private (non-financial) sector (see for instance Jordà et al. 2015 and Borio and Disyatat 2011). During the upswing as refinancing conditions are eased by the central bank, the commercial banks can only extend credit by lowering lending rates. As credit to the private expands, the average marginal return of financed investment projects declines. For instance, during the US real estate boom financing of prime projects as followed by subprime projects. As shown in Figure 6 the strong

16 For details see Schnabl and Hoffmann (2008).

17 The natural interest rate is a theoretical concept, which is empirically not traceable. In Wicksell (1898) the natural interest rate is understood as the interest rate which balances savings (future consumption) and investments (future production) at price stability. In this equilibrium an inflationary credit boom does not take place. In the theory of Hayek (1929) a fall of the central bank interest rate below the natural interest rate triggers credit-driven distortions in the structure of the economy, which have to be sooner or later corrected during a recession. This corresponds to a cleansing process. 
increase of the credit provision of Japanese banks to the private sector during the bubble economy. Similarly, in China credit to the private sector (including financing via the shadow banking sector) started to expand fast since the turn of the millennium and further accelerated since 2008.

Figure 6: Credit to the Private Sector in China and Japan

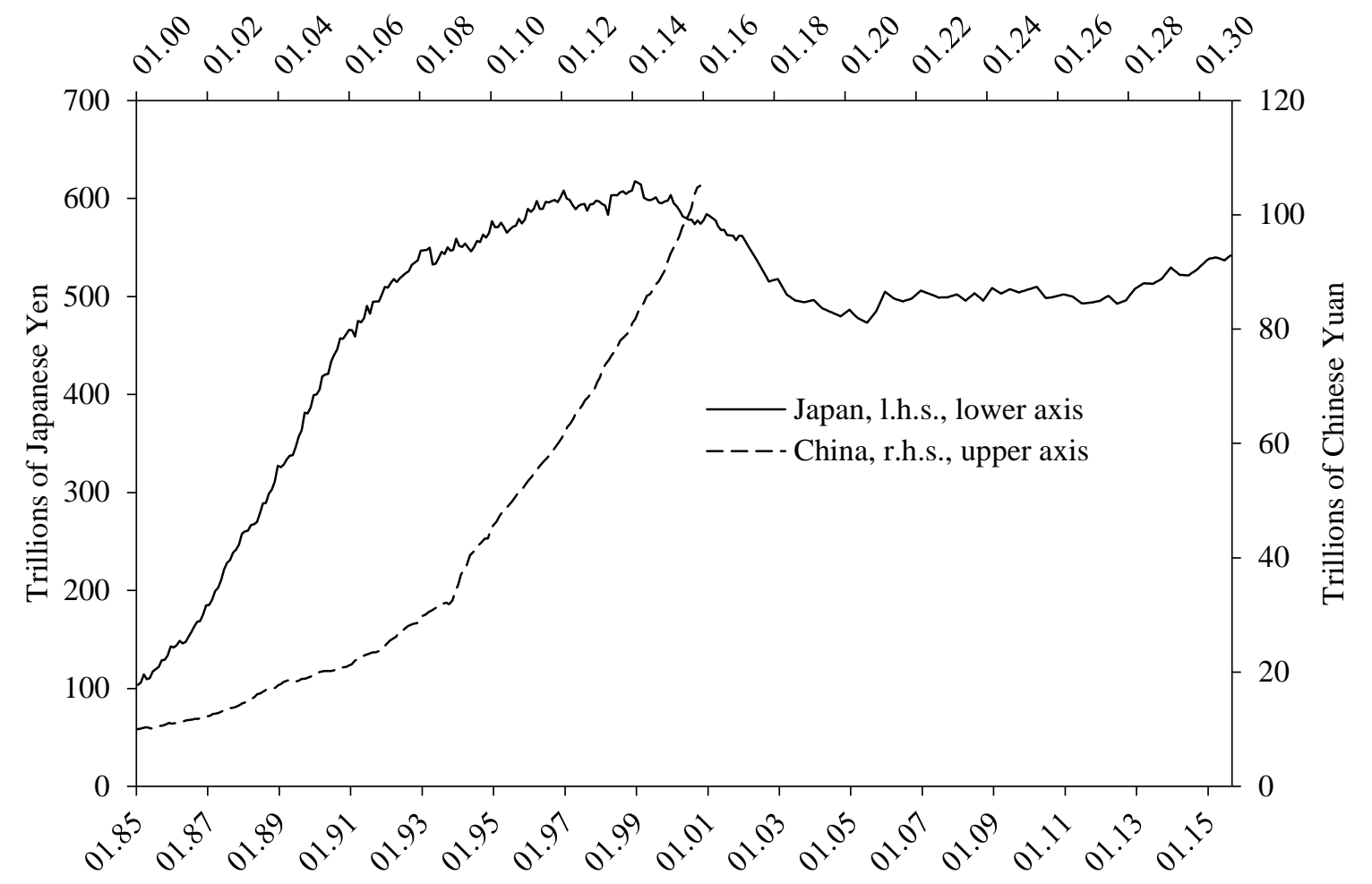

Source: IMF: International Financial Statistics, quarterly data.

The Japanese bubble economy was a credit-driven credit boom as modelled by the overinvestment theories. Because the strong appreciation of the Japanese yen caused a strong recession in the export-dependent Japanese economy, the Bank of Japan felt tempted to cut the interest rate from 8\% in October 1985 to 3.3\% in July 1987, i.e. to a historically low level (Figure 4). By cutting interest rates, the Bank of Japan let adjust the domestic interest rate level to the speculative capital inflows, which had been generated by one-way bets on publicly announced yen appreciation. The interest rate cuts of the Bank of Japan not only facilitated investment by Japanese export enterprises to regain international 
competitiveness. ${ }^{18}$ Investment as percent of GDP increased from $27.7 \%$ in 1985 to $32.1 \%$ in 1990.

Figure 7: Real Estate and Stock Prices in China and Japan

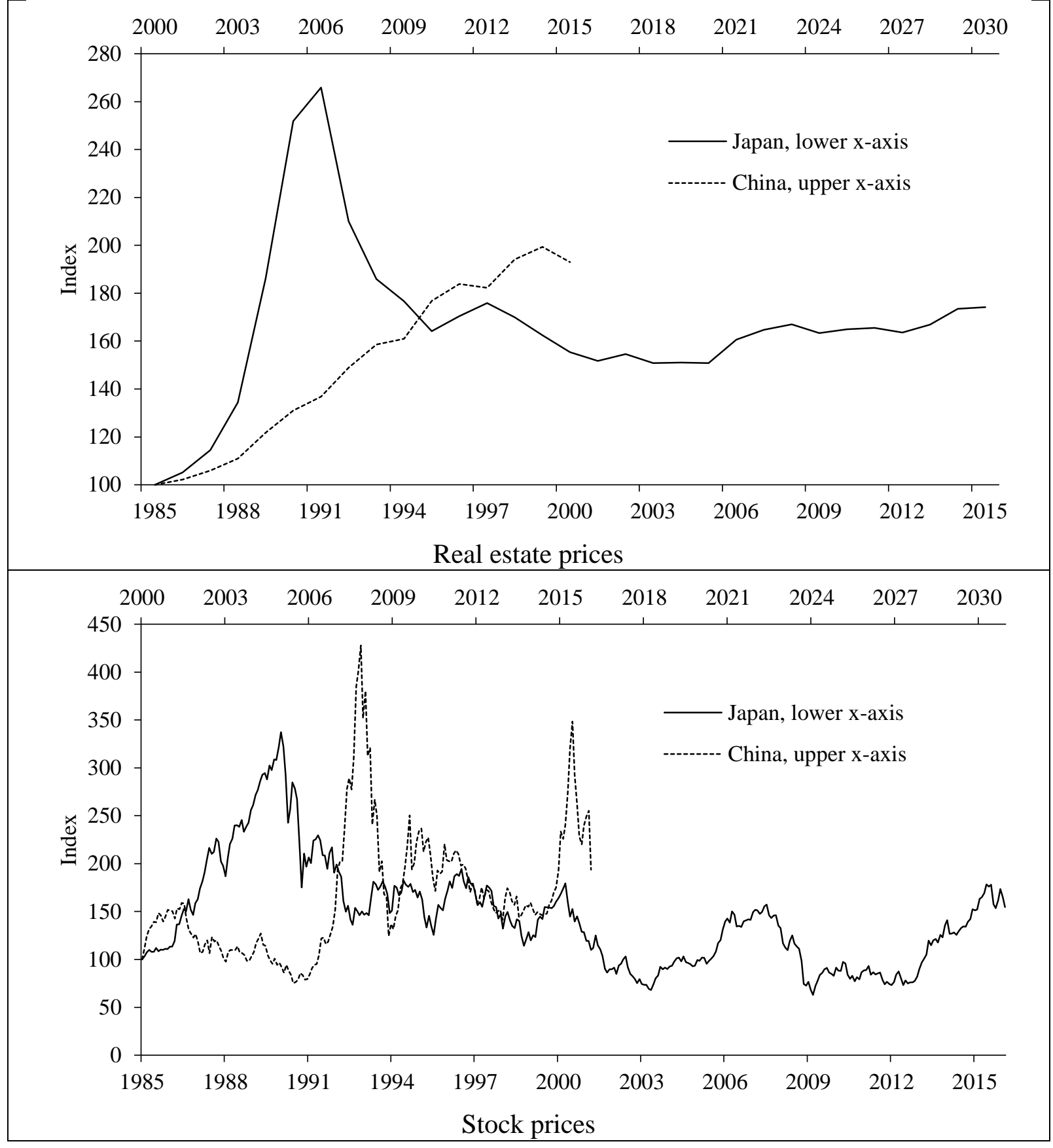

Source: Oxford Economics, Shanghai Stock Exchange, Nikkei. Index: 01.1985 = 100 (Japan), $01.2000=100$ (China).

18 The interest rate cuts of the Bank of Japan could go rather far without pushing up inflation, because together with the yen appreciation the recession and the restructuring of the Japanese economy had a deflationary effect on prices in yen. 
It also contributed to a stock and real estate boom on the back of rapidly accelerating credit growth. The Nikkei 225 hiked from about 15.000 points in January 1985 to closely below 40.000 points in December 1989 (lower panel Figure 7). Real estate prices, in particular in the metropolitan areas, increased to unprecedented levels (upper panel of Figure 7). In densely populated Japan real estate became a widely used collateral for speculative stock purchases. The expansionary fiscal policy following the Louvre-Accord (February 1987) added further momentum to the bubble.

As in the monetary overinvestment theories of Wicksell (1898), Mises (1912) and Hayek (1929), the central bank put an end to Japans speculation boom by increasing interest rates. ${ }^{19}$ By 1988 the Bank of Japan acknowledged that the stock and real estate boom, which was transmitted via wealth effects into a consumption boom, was not sustainable and lifted interest rates to deflate the bubble (upper left panel of Figure 4). Real estate transactions were tried to be hampered by tighter regulations and higher taxes. In December 1989 the stock market bubble burst (upper panel of Figure 7), in 1991 the upward trend on real estate markets was reversed (lower panel of Figure 7). As in the monetary overinvestment theories, the Bank of Japan kept monetary conditions tight until 1991 to ensure a consolidation of the artificially inflated credit to the private sector in the balance sheets of commercial banks. ${ }^{20}$

Thus, in the the early years of the crisis the Bank of Japan cut interest rates only hesitantly, probably keeping interest rates above the natural level. However, as the crisis persisted interest rates were cut more decisively and reached $0.5 \%$ in the mid 1990 s (Figure 4). With the acceleration of interest rate cuts, investment in Japan did not recover. Instead, capital outflows from Japan contributed to overinvestment as well as stock and real estate booms in a set of Southeast Asian countries (Schnabl and Hoffmann 2008). Low cost capital could be raised in Japan and invested in Southeast Asia, where the interest rate levels and expected returns of investment were much higher. ${ }^{21}$ By participating in the Southeast Asian (so-called) economic miracle Japanese banks and enterprises could counterbalance the losses originating

19 The monetary overinvestment theories assume that the central bank keeps the interest rate above the natural interest rate during the downturn, which aggravates the recession.

20

Both the restrictive monetary policy in response to the bubble as well as the restrictive monetary policy stance during the first phase of the post-bubble recession were ex post seen as monetary policy mistakes (e.g. Posen 2000). Bernanke (2000) dubbed the Japanese post-bubble stagnation of the 1990s as "self-induced paralysis", which could have been avoided by decisive monetary expansion and "unconventional measures" such as outright purchases of government bonds, helicopter money, and/or discretionary currency depreciation.

21 The returns from positive interest rate spreads were threatened to be turned negative by potential yen appreciation versus the investment currencies. Yet, this risk was mediated by foreign exchange intervention against yen appreciation. Also, interest rate cuts softened yen appreciation pressure. This made carry trades a lucrative source of income. 
in the bursting of the Japanese bubble economy. However, when the Southeast Asian investment boom found its end with the 1997/98 Asian crisis, Japanese banks and enterprises suffered from new painful losses in terms of new bad loans (banks) and overinvestment in now idle - production sites (enterprises).

\section{Figure 8: Japanese Foreign Direct Investment to China and U.S.}

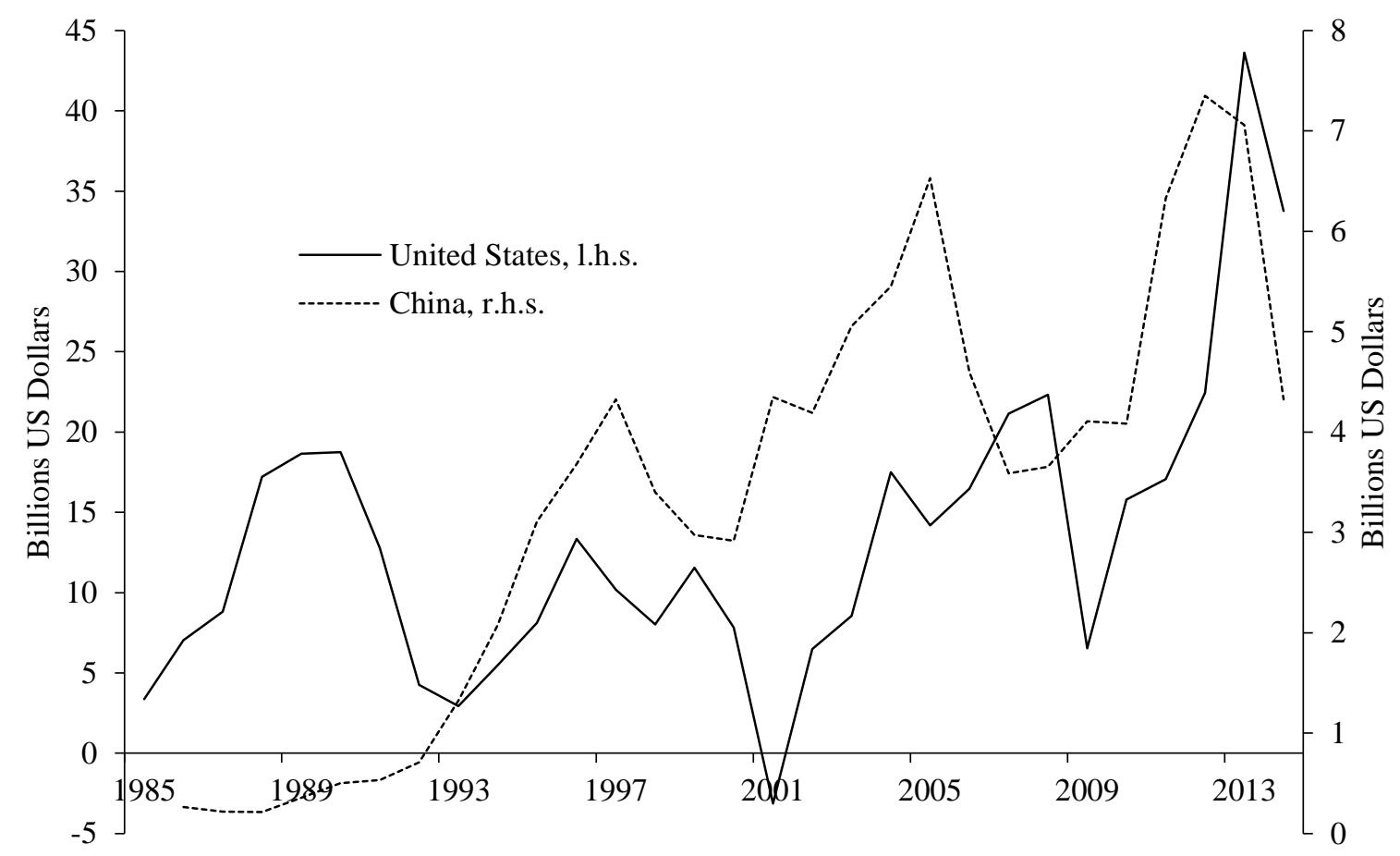

Source: National Bureau of Statistics of China, Bureau of Economic Analysis, U.S. Department of Commerce.

The Asian crisis was transmitted to Japan via goods and financial markets resulting in the Japanese financial crisis (1998). Because in response to the Japanese financial crisis Japanese monetary policy became even more expansionary in the form of quantitative easing, net capital outflows and the current account surpluses persisted. After the turn of the millennium, there were two main destinations of Japanese capital exports. Portfolio investment and FDI (Figure 8) remained focused on the U.S., where stock prices continued to rise. In addition, with the restructuring process of the Japanese export industry gaining further momentum, China became an increasingly important target of Japanese foreign direct investment (FDI) (Figure 8). This implies that Japanese investors in general and Japanese enterprises in specific increasingly participated in China's high growth and therefore contributed to the build-up of overcapacities in the Chinese industry. 


\subsection{Financial Market Repression and Bubbles in China}

In contrast to Japan, financial markets in China were much less liberalized and developed, when the influx of speculative liquidity accelerated after the turn of the millennium. Because the Chinese stock market is underdeveloped and the government debt level is comparatively low, Chinas absorption capacity for portfolio capital inflows has been comparatively small. In addition, the commercial banks of China are mostly state-owned, with banks being subject to public guidance (Cull and Xu 2003). Despite substantial liberalization achievements interest rates were and still are subject to regulation (McKinnon and Schnabl 2014).

Up to the present, a set of inward and outward bound capital controls - with the yuan being not freely convertible - maintain a firewall between the Chinese and the international capital markets. This allows China to isolate domestic monetary policy from the monetary policies of other large countries. As shown in Figure 4 the money market interest rates in China stayed significantly above the U.S. interest rate, although in the view of the open interest rate parity persistent appreciation expectations would have implied a lower interest rate in China than in the U.S. to ensure international portfolio balance equilibrium.

The acceleration of capital inflows via foreign direct investment, repatriation of receipts from current account surpluses and hot money inflows constituted after the turn of the millennium the breeding ground for overinvestment and hiking real estate prices for changing reasons. First since 2001, the interest rate cuts of the Federal Reserve (and other central banks of large industrialized countries) in response to the bursting dotcom bubble provided a push factor for private capital flows into emerging markets in general. Second, among the emerging markets China was a very attractive target for capital inflows - in particular for FDI - because of the qualified low-cost labour force, the giant market and positive growth expectations.

Third, after the Federal Reserve had started to increase interest rates from 2004, the Peoples Bank of China moved towards a controlled appreciation path, which invited one-way bets on the yuan. Appreciation expectations on the yuan provided an incentive for persistent capital inflows to China despite increasing interest rates in the U.S.. ${ }^{22}$ Even more, with profit expectations in the U.S. real estate market faltering, funds could be reallocated to China. Forth, when the yuan was re-pegged to the dollar in July 2008, the Federal Reserve had already dramatically cut interest rates again and moved towards quantitative easing in response to the subprime crisis. This reanimated private capital outflows from the U.S..

22 The rapid foreign reserve accumulation of the Peoples Bank of China was to a large share invested in US government bonds, what kept U.S. long-term interest rates low despite short-term interest rate increases. 
With the resulting appreciation pressure apparently going beyond the official target, the Peoples Bank of China accumulated since January 2001 foreign reserves at a growing speed. Chinas foreign reserves reached their peek in July 2014 at an equivalent of close to 4 trillion dollars (Figure 5). In the early phase of the Chinese dollar peg up to the year 2004, continual purchases of foreign exchange by the Peoples Bank of China were the main instrument for increasing the monetary base. Before 2005 when the yuan was not expected to appreciate, these purchases generally amounted to less than 100 percent of the growth in base money. Sterilization operations were not necessary to contain inflation. In this fixed rate period, the rapid increase in the demand for base money originating from China's high growth, combined with an income elasticity of money demand greater than one, more or less balanced the rapid increase in money supply.

But with the acceleration of capital inflows and reserve accumulation since 2005 inflationary pressure would have substantially grown. Inflation usually picks up first in the food and energy markets. As in low-income countries such as China a substantially larger share of income is spent for food and energy, the population is more sensible to inflation. ${ }^{23}$ Therefore, the Peoples Bank of China took measures to sterilize the monetary effects of foreign reserve accumulation. It sterilized the monetary effects of foreign reserve accumulation by selling government bonds, by increasing the share of reserve requirements and by extending the basis for calculating reserve requirements (McKinnon and Schnabl 2012). To minimize sterilization costs, the remuneration rate for required reserves was kept low, between one and two percent, i.e. substantially below the inflation rate. At the same time the upper limit for lending rates was maintained. ${ }^{24}$

The extensive non-market-based sterilization process not only helped to dampen inflationary pressure in China, it also opened the door for a state-directed investment promotion via socalled window guidance. ${ }^{25}$ By keeping the lending rate below the market clearing level ${ }^{26}$, a surplus demand in the Chinese capital market was created. This puts the government into the

23 In the industrial countries the recent tremendous monetary expansion was mainly absorbed by capital markets. Because this is not possible in countries with underdeveloped capital markets to the same extend, consumer price inflation is more sensible to monetary expansion.

24 In the first phase liquidity was absorbed from the banking sector by selling central bank bonds (at more or less close to market rates). This market-based sterilization had two downsides: Substantial costs for the central bank emerged, as interest had to be payed on the central bank bonds. Furthermore, the resulting rise of interest rates following the domestic monetary tightening attracts additional speculative capital inflows and thereby makes additional reserve accumulation and sterilization operations necessary.

25 Preferential treatment of specific sectors and enterprises via window guidance (madoguchi shidô) was a common way of credit allocation during the catch-up process of Japan (Hamada and Horiuchi 1987: 244246).

26 What correspond to non-market-based sterilization. 
position to discretionarily allocate credit to specific enterprises via the state-controlled banking sector. ${ }^{27}$ Two strategies of credit allocation are likely to have dominated. First, investment of the enterprise sector was likely to receive preferential treatment for financing rather than the household sector (which tends to finance consumption). Second, within the enterprise sector, large state-owned enterprises (SOEs) and exporters were the prime beneficiaries of state-directed capital allocation. Private small and medium enterprises (SMEs) tended to be short of credit.

The lower panel of Figure 9 shows the resulting change in the economic structure of China since the turn of the millennium. Investment as a share of GDP gradually increased from 33\% in 2000 to $44 \%$ in 2014. The large build-up of capacities, mainly in the Chinese manufacturing sector, can be seen as overinvestment in the sense of the monetary overinvestment theories: Via the preferential allocation of capital at below market rates (i.e. below the natural interest rate), the Chinese government created overcapacities in the manufacturing sector ${ }^{28}$, which ceteris paribus could not be absorbed by domestic or foreign demand (see section 4b).

As the preferential capital allocation via window guidance was combined with interest rate controls, the shadow banking sector was fostered and overcapacities in the real estate sector were created. Un- or low-remunerated reserve requirements constitute a source of opportunity cost for the private banking sector in form of the gap between the remuneration rate for required reserves and the lending rate. In the case of China this spread can be assumed to have been roughly around 4.5 percentage points since the year 2005. In the face or such financial repression, banks have to shift the costs to their customers either in form of higher lending rates or lower deposit rates to maintain profitability (Löffler et al. 2013).

Given an upper ceiling on lending rates in China, it can be assumed that deposit rates were depressed. Between 2012 and 2014 Chinese deposit rates were around 3\% (for one-year time deposits), i.e. mostly below the inflation rate. This provided an incentive to withdraw deposits from state-owned banks and to funnel them into the shadow banking sector. The shadow banks tended to use these funds to finance real estate projects and small and medium enterprises. That drove via low-cost funding prices in the real estate market. Investment in

\footnotetext{
27 "The PBC will strengthen window guidance and credit guidance to intensify efforts to adjust the credit structure. Efforts will be made to optimize the credit structure, to encourage growth in some sectors while discouraging growth in others.“ (China Monetary Policy Report Quarter 2, 2008: 13)

28 On the build-up of overcapacities in China see European Chamber (2016).
} 
real estate projects was very profitable as long as real estate prices could be expected to rise. That was - probably - the case until mid 2014 (see upper panel of Figure 7).

Figure 9: Structure of Gross Domestic Product of China and Japan

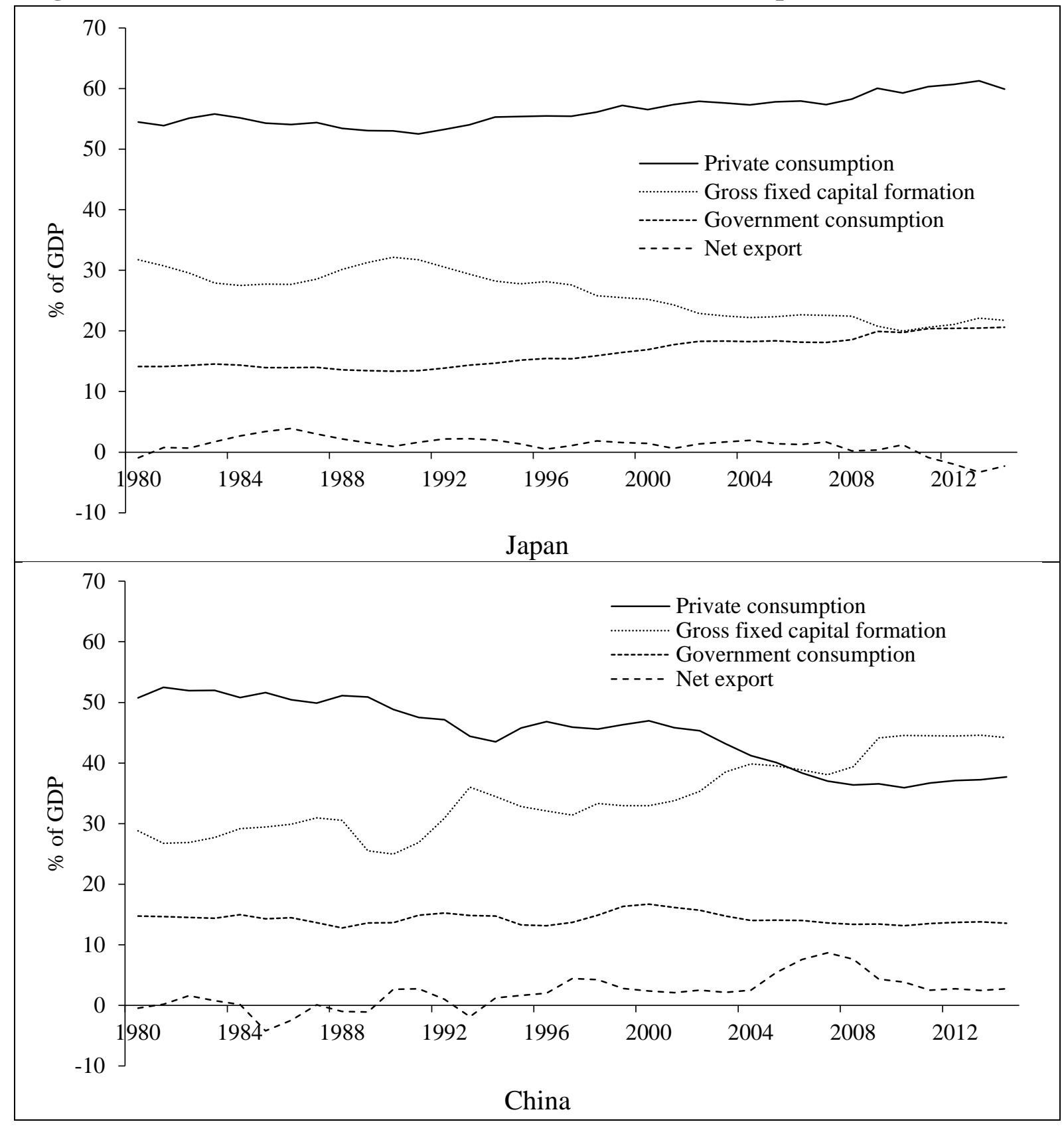

Source: IMF International Financial Statistics.

The positive impact of low interest rate policies on real estate prices creates a link to increasing savings and thereby depressed consumption of the household sector via two transmission channels. First, given expectations of rising real estate prices household investment in real estate is encouraged. Ma, Roberts and Kelly (2016) provide empirical 
evidence in favour of growing real estate investment of the household sector. Second, to finance future real estate purchases - with prices being expected to rise - households have to build additional precautionary savings and thereby curtail consumption. In this context, Wei and Zhang (2011) argue that in particular young men increased saving efforts to purchase housing to signal their prosperity in the marriage market. Consumption as a share of Chinese GDP continuously declined from 47\% in 2000 to 38\% in 2014.

The prospects of the future development of investment in the Chinese manufacturing sectors and the real estate sector have become increasingly gloomy. The monetary overinvestment theories would suggest, that at one point of time, inevitably, the economic turnaround will occur. This is usually the case when the central bank tightens the monetary conditions or private capital markets lose confidence in the economic upswing. The first was the case in Japan at the end of the 1980s, the latter seems to currently occur in China. ${ }^{29}$ During 2015, Chinese exports to many emerging market economies slowed down, as - given rising interest rates in the U.S. - growth in the emerging world slowed down. Furthermore, the strong depreciation of the Japanese yen against the dollar and the yuan constituted a growing obstacle for the Chinese trade performance. News about growing overcapacities in the Chinese industry (European Chamber 2016) and in the Chinese real estate sector (Lerbs 2015) became denser.

The growing depreciation pressure on the Chinese yuan, which is accompanied by significant losses of foreign reserves of the Peoples Bank of China (Figure 5) indicates a reversal of speculative capital flows. As interest rates in the U.S. are expected to increase, expected returns in China are on decline, and the yuan is expected to depreciate against the dollar, it seems rational to convert yuan into dollar. ${ }^{30}$ Monetary expansion as crisis response creates additional depreciation pressure on the yuan. Depreciation pressure is caused by not converting export revenues into yuan and by converting yuan into dollar assets. Repetitive

29 In contrast to the Bank of Japan the Peoples Bank of China has responded to changing economic sentiment by prompt interest rate cuts and loosening reserve requirements.

30 Again, with depreciation becoming predictable, the private sector gains, whereas the public sector looses. Now, as the resulting bubbles in the real estate sector and in the export sector have burst and - given expectations about rising interest rates in the U.S. - private investors want to hold more dollar assets, a depreciation of the yuan is widely expected. If we expect for instance a yuan depreciation of $3 \%$ per year, Chinese interest rates to fall towards $0 \%$ and U.S. interest rates to increase to $4 \%$, the expected return is again $7 \%$ for the ones, who can make it around the outward-bound capital controls. The central bank again feels forced to stabilize the exchange rate, because now exchange rate stabilization is equivalent to financially stabilizing enterprises, real estate firms and (shadow) banks with large dollar exposure. This prevents (postpones) an even deeper financial turmoil. For this purpose the Peoples Bank of China is forced to buy yuan and sell dollars, which implies in the setting above a negative return of $-7 \%$ on the respective transaction volume. In effect, dollar assets with high expected return are substituted by Chinese assets with low expected return. 
steps towards monetary expansion by the Peoples Bank of China reveal concerns of Chinese policy makers with respect to future economic development. The depreciation of the yuan against the yen also puts the stage for competitive depreciations with Japanese yen and other smaller East Asian currencies (see Schnabl and Spantig 2015).

As financial markets in China are less developed and less free market-based than in Japan, the end of an overinvestment boom and the bursting real estate or stock market bubbles are unlikely to become visible in a similar erratic way as it was the case in Japan. This is in particular the case in the stock market, where prices have only limited information content because of comparatively low capital market capitalization and extensive government interventions. Nevertheless, starting from summer 2015 sharp shocks in the Chinese stock markets indicated a change in economic sentiment (lower panel of Figure 7). All in all, the end of the overinvestment boom may be best indicated by announcements of Chinese policy makers that the export-led growth strategy is to be transformed into domestic demand-led growth.

\section{Long-term Growth Effects in Japan and Lessons for China}

As shown above for both Japan and China the current account imbalances and the exchange rate conflict with the U.S. constituted the breeding ground of speculative self-reinforcing capital inflows. In both cases the result has been speculative bubbles and structural distortions, which have taken the form of overinvestment (in particular China) and unsustainable booms in the stock and real estate markets (Japan and China). Once bubbles burst, the question about the adequate crisis therapy arises. The Keynesian approach is to move towards fiscal and monetary expansion to sustain growth and to prevent unemployment in the short-term (Keynes 1936, Eggertson and Krugman 2012, De Grauwe and Ji 2013). In contrast, Hayek $(1929,1944)$ warned from curing a deflationary process with the injection of cheap liquidity and increasing public demand, because distorted structures of the economy are conserved and growth is paralyzed in the long-term. This is observed in post-bubble Japan. What are the implications for China? 


\section{a. Paralyzed Growth Dynamics in Post-bubble Japan}

Although, in particular in early years of the post-bubble crisis Japan hesitated to move towards monetary expansion as a crisis therapy, interest rates converged finally towards zero and extensive unconventional monetary policy measures were put on track (Posen 2000, Ueda 2012). The Bank of Japan balance sheet was gradually inflated by purchase programs for stocks, bonds, government bonds and preferential credit provision to small and medium enterprises. With the Abenomics this process gained further momentum from 2013. The size of the Bank of Japan balance sheet reached ever higher levels (Figure 10).

Although, expansionary monetary and fiscal policies are likely to have prevented a deep recession in the short-term (see for instance Koo 2005) they paralyze in the view of the overinvestment theories growth in the long term (Schnabl 2015). With the bursting of the bubbles in stock and real estate markets a large stock of bad loans emerged of which the size is dependent on the anticipated level of interest. Given expectations that zero-cost liquidity provision will persist, banks become tempted to perpetuate loans to enterprises independent from the profitability. This strategy prevents that even more bad loans become visible. Yet, so-called "zombie banks" become dependent on low-cost liquidity provision by the central bank because the zero interest rate policy erodes traditional sources of income such as the lending-deposit-spread and credit provision to the large export enterprises.

\section{Figure 10: Central Bank Balance Sheets (as share of GDP)}

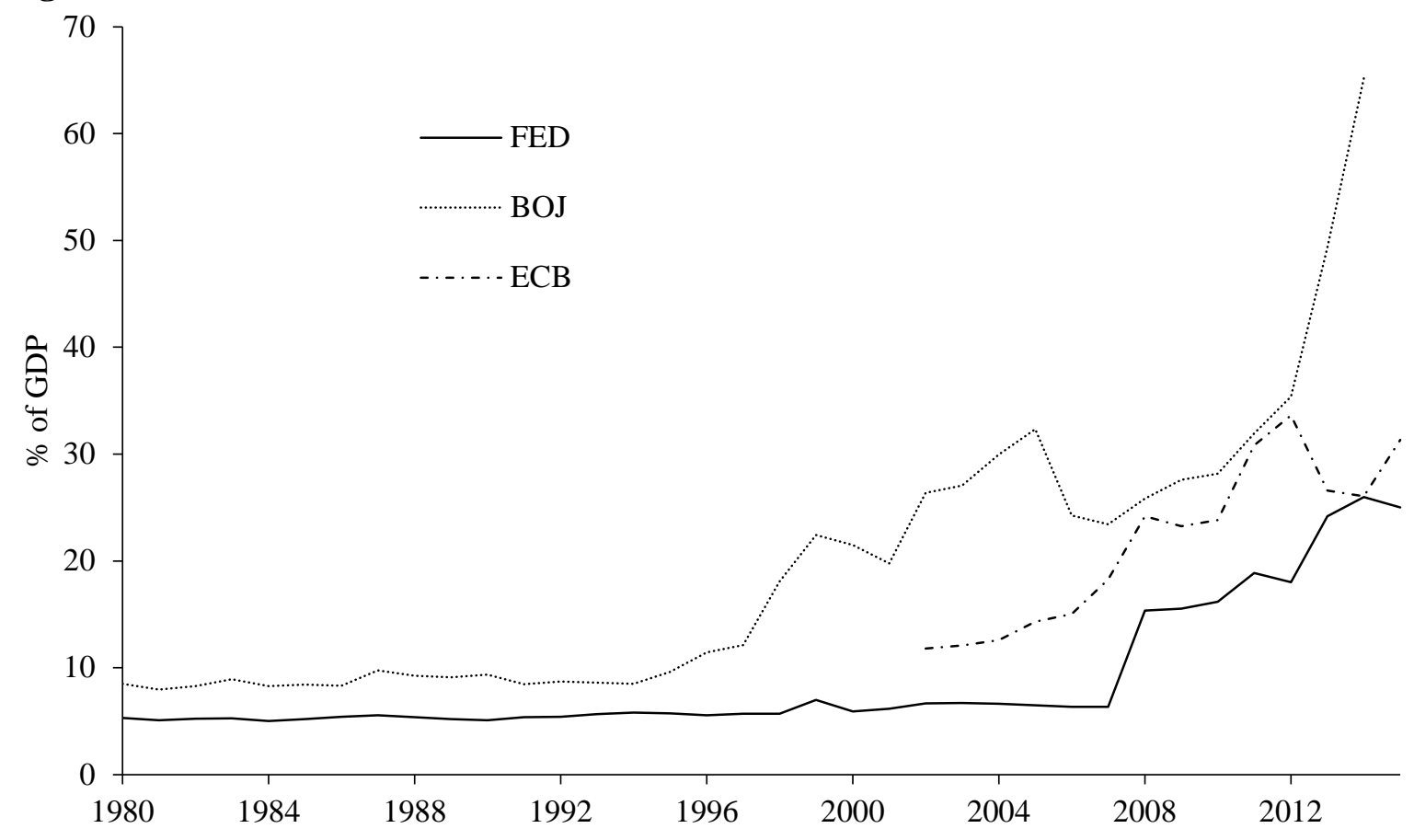

Source: IMF, Bank of Japan (BOJ), European Central Bank (ECB). 
Caballero, Hoshi and Kashyab (2008) stress the impact of zombie lending on the Japanese enterprise sector, as low-profit enterprises are kept alive and distorted economic structures are conserved. Sekine, Kobayashi and Saita (2003) argue that forbearance lending emerged with credit to the private sector becoming increasingly disconnected from the profitability of investment projects. Peek und Rosengren (2005) identify a misallocation of capital through the credit sector which keeps enterprises with low or negative profit expectations alive without pricing risk (,evergreening“).

Forbearance lending affects the productivity of enterprises (Hoffmann and Schnabl 2016). In the neoclassical growth model of Solow (1956) and Swan (1956) long-term growth (beyond the steady state) is generated by innovation and technological progress (i.e. productivity gains). The Japanese monetary policy, which cut interest rate to zero and gradually expanded the central bank balance sheet via quantitative easing, has within this framework a negative impact on productivity: If economic agents anticipate further monetary expansion, efforts to innovate and to achieve higher productivity gains are subdued. ${ }^{31}$

By shifting and tying resources to sectors with low or negative productivity gains, in the Solow-Swan model a negative allocative effect is created which results from declining average productivity (defined as output per unit of labor). Average costs will rise ceteris paribus. At the macroeconomic level, the additional amount of goods and services to be produced with a constant amount of labor is shrinking or even becoming negative. Since declining output also entails a decrease in savings per worker, this results in an additional negative growth effect because households make fewer savings available for investment. ${ }^{32}$

At the root of the problem is the misallocation of funds, which is caused by the fact that low interest rates encourage structural distortions in the speculative upswing and monetary expansion as a crisis therapy conserves these distortions during the downswing. Even more, the monetary policy crisis response deprives the interest rate of two functions. (1) The signaling function, which indicates default risk. (2) The allocation function, which separates investment projects with high expected returns from investment projects with low expected

31 Hayek (1968) created the notion of Competition as a Discovery Procedure: A high degree of competition ensures dynamic efficiency by providing an incentive for innovation and imitation. Innovation is profitable, because it creates monopolistic rents. The imitation process provides an incentive for coming up with new innovation, because monopolistic rents are destroyed by imitation. In a monetary-policy context ensuring profit margins by reducing cost of capital erodes the efforts to gain efficiency in the production process or to create monopolistic rents by coming up with new products.

32 Household savings and gross investment as a share of output tend to decline in all major industrialized countries since the mid 1980s. 
returns. De facto the liability principle of market economies is suspended, because banks and enterprises, which would not be able to survive at a higher interest rate, are kept alive. Figure 11 shows the declining productivity gains in Japan (and other industrialized countries) since the bursting of the bubble economy.

The ultra-loose monetary policy in Japan has to be perpetuated for at least two reasons. First, after the bursting of the bubble the Japanese government debt continued to increase on the back of declining tax revenues and high costs of crisis management up to 250\% of GDP by 2015. The central bank cannot increase the interest rate, because this would inflate the future interest rate burden and thereby turn the government virtually bankrupt. Also the central bank itself would suffer from substantial losses, as it holds large amounts of government bonds and other high-risk assets. The necessary recapitalization by the government would undermine the central bank’s independence.

Figure 11: Productivity Increases in Japan, Germany, U.S. and China

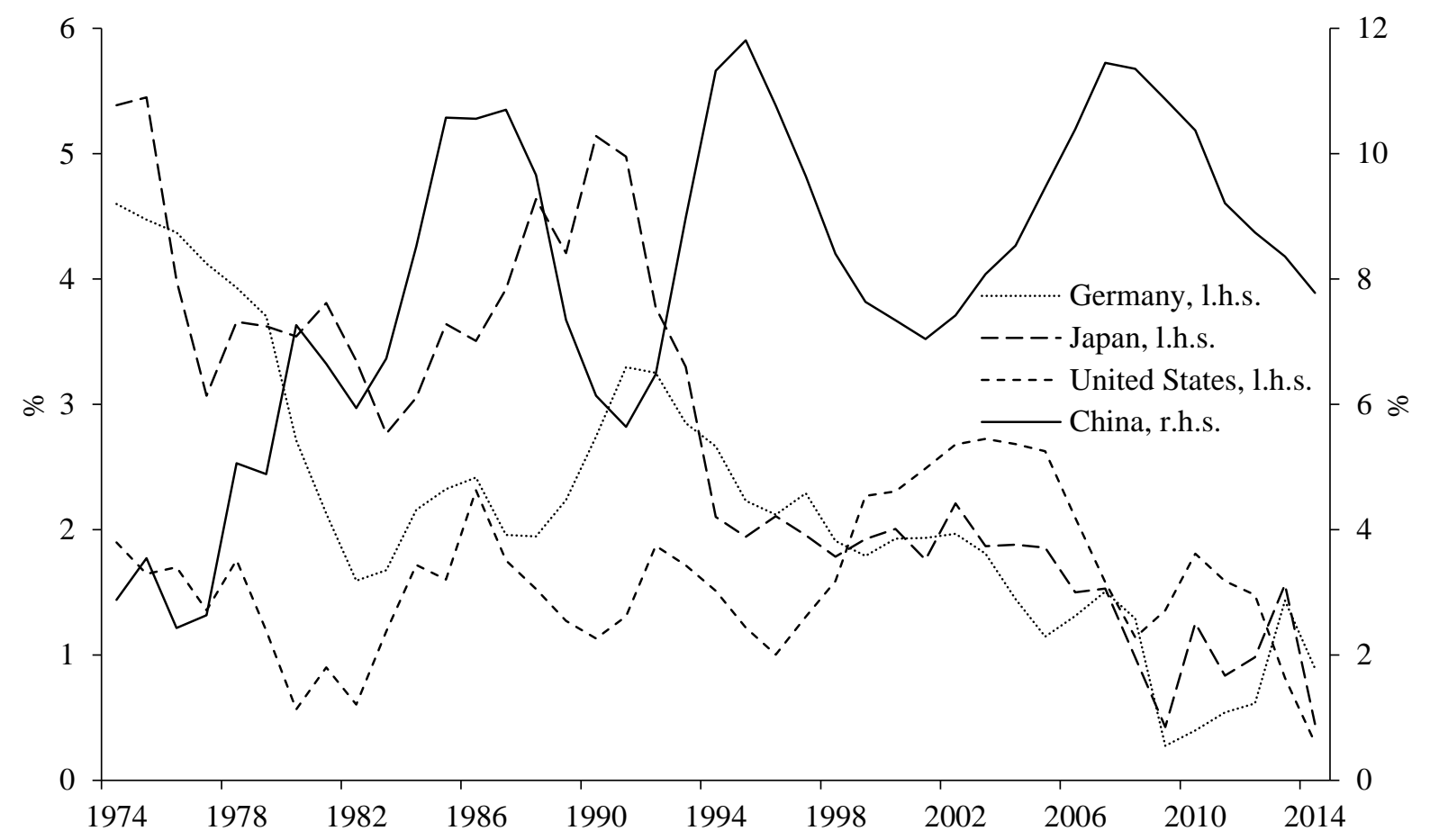

Source: OECD.

Second, the very loose monetary policy tends to have in the industrialized countries a deflationary (instead of inflationary) impact on consumer prices (Hoffmann and Schnabl 2016). Because the effects of the ultra-low monetary policies primarily show up in the asset markets, they have redistribution effects in favor of the high-income classes (which hold the 
largest shares of these assets). The real incomes of the middle-income and low-income classes - of which the consumption behavior is modelled by the consumer price indices - are step by step eroded via real wage repression and financial repression. Because this process depresses consumer price inflation, the Bank of Japan can continue to extend its balance sheet without violating its inflation target.

\section{4b. Policy Recommendations for China}

During the past wave of wandering bubbles and in particular during post-bubble crises (Japanese post-bubble crisis, Asian crisis, U.S. subprime crisis etc.) China has played an important stabilizing role for the world economy (McKinnon and Schnabl 2009), because growth was (kept) high. The gradual market-oriented reforms initiated by Deng Xiaoping starting from the late 1970s unchained private initiatives, which have been up to the present the backbone of the outstanding Chinese growth performance. The Chinese catch-up process was further strengthened by the adoption of IMF current account convertibility in 1994, which boosted the integration of China in the world economy.

Since the turn of the millennium and in partiuclar since the adoption of an predictable downward crawling peg China's catch-up process has shown signs of overheating. These can be rooted in a very low-interest rate environment in Japan and U.S. (and also euro area) combined with state-directed capital allocation via a state-owned banking sector. In the view of the overinvestment theories of Wicksell (1898), Mises (1912) and Hayek (1929) overinvestment in the export sector and the real estate sector has emerged. Currently this overinvestment is discussed in the context of overcapacities.

For a certain time period the sterilization policy as described in section 3.2. helped to clear the overcapacities in the Chinese industry on the world market. Given a fixed exchange rate to the dollar (or an appreciating nominal exchange rate of the yuan against the dollar) - unsterilized foreign exchange intervention of the scale as observed in China would have triggered a significant inflationary pressure and thereby real appreciation of the yuan against the dollar. Chinese (foreign) exports would have lost (gained) competitiveness. The immense capacities 
of the Chinese export sector would have increasingly turned idle and would have been accompanied by a declining (growing) current account surplus (deficit). ${ }^{33}$

With sterilization, however, - because consumer prices and producer prices could be held low compared to the U.S. and world markets - the real exchange against the dollar remained widely constant since the turn of the millennium despite extensive foreign reserve accumulation (see Figure 12). Thus, in contrast to Japan, the nominal appreciation of the yuan against the dollar was not accompanied by a loss of competitiveness. In effect, the clearance of overcapacities was ensured by subsidized capital allocation and real exchange rate stabilization. This strategy became undermined, when staring from 2013 growth in emerging market economies considerably slowed down and growth in the industrialized countries remained sluggish. In addition, the strong yen depreciation in the course of the Abenomics gradually undermined the competitiveness of Chinese exports relative to Japanese exports in the world market. The export-oriented investment and growth model of China is stumbling.

Figure 12: Real Exchange Rate (RER) of the Yuan against the Dollar

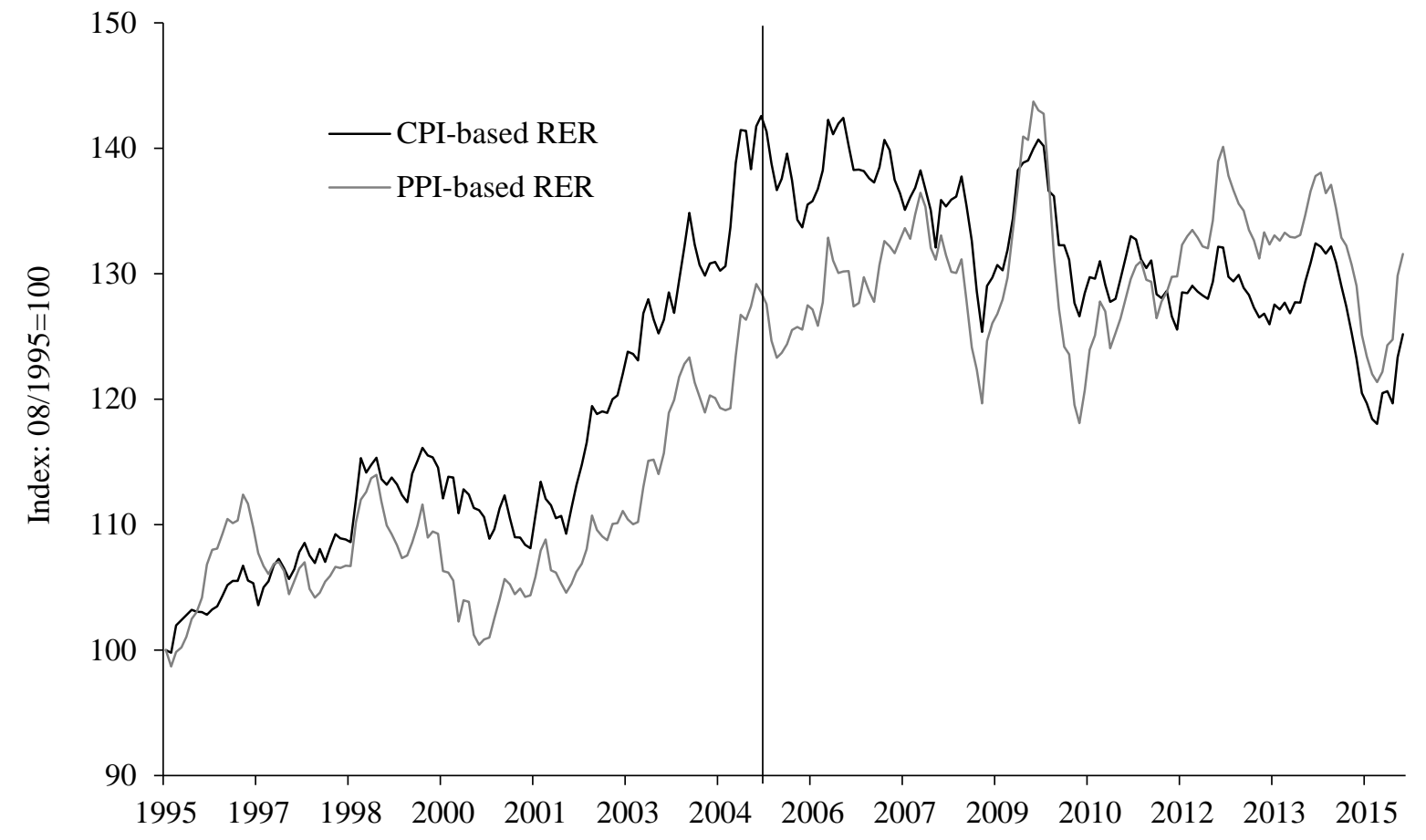

Source: IMF. Own calculations. Declining values correspond to real appreciation of the yuan.

To cure the current slow-down of growth, China has the potential to follow a similar crisis therapy as observed in Japan (and meanwhile other important industrialized countries such as

33 This was the case in the Southeast Asian countries prior to the Asian crisis. 
the U.S. and the euro area). The scale to expand debt-financed government expenditure is large, because general government debt is with around 40\% of GDP far below the level in Japan and most other industrialized countries. Also monetary policy has a large potential to further expand, as the large scale of sterilization measures can be reversed. This could help to keep Chinese growth close to a specific (but possibly slowly declining) target. Yet, the economic consequences are likely to be similar as in Japan. Credit allocation via the stateowned banking sector would be not fully oriented towards profitability. Enterprises' productivity gains would deline and growth would further slow down. As income per capita is in China substantially lower, dissatisfaction among the population may grow faster despite still higher growth than in Japan.

Therefore, the crisis therapy of China should be based on the monetary overinvestment theories. Overinvestment in the export and real estate sector should be dismantled to free capacities for more dynamic investment projects. Due to the fact that China is still in the economic catch-up process, it should be easier than in Japan to overcome structural distortions because the growth potential is higher than in Japan. As experienced in Japan, high growth rates in the 1970 s facilitated the liberalization process of capital markets and real wages (Fukumoto and Muto 2012).

This economic policy strategy could be based on two pillars. First, as the industrialized world including Japan is likely to remain in an ultra-low interest rate environment, China should maintain/tighten its inward-oriented capital controls. This would help to shield off the country from speculative capital inflows that encourage speculative, low-yield investment rather than investment with high marginal returns. An intrest rate of close to zero is far too low for a country in the economic catch-up process with still a considerbly higher level of productivity gains than the industrialized countries (Figure 11).

Second, a fixed exchange rate strategy with a tight horizontal peg to the dollar should be pursued. The pre-2005 experience of China has shown, that for a country in the economic catch-up process with underveloped capital markets a fixed exchange rate provides a stabilizing framework for investment and growth. In contrast, predictable exchange rate paths - both towards apprecition and depreciation - encourage destabilizing speculative capital flows as experienced since July 2005. These should be subdued, because they have proven as crisis-prone for emerging market economies, in particular because the absorption capacity for speculative capital inflows is comparatively small. 
A fixed exchange rate of the yuan against the dollar would also help to prevent competitive depreciations of the East Asian currencies, which are likely to destabilize the economic development of the region as a whole. Instead of allowing the yuan to depreciate against dollar China should use a fixed rate to the dollar as a leverage to bargain for an end of the depreciation strategy of the Japanese yen against the dollar. Exchange rate stability between yen and yuan would also foster overall intra-regional exchange rate stability as a prerequisite for stable long-term growth in China in specific and in East Asia in general. This strategy would also enhance the international role of the yuan in East Asia as it was observed for the German mark in Europe prior to the introduction of the euro.

The fixed rate of the yuan against the dollar would allow the Chinese authorities to run effectively a Keynesian debt-financed stimulus package, which would under flexible exchange rates be turned ineffective by yuan appreciation and interest rate increases. Such a program (which is at best based on tax cuts) would support the rebalancing of the Chinese economy towards domestic demand. Given that U.S. monetary policy is expected to be tighter in the future, Chinese monetary policy would be preserved from the temptation to move towards similar monetary expansion as oberserved in Japan. The extraordinary monetary expansion in Japan has been in the long-term a source of declining investment, shrinking productivity gains and lower growth. China could therefore maintain a hard budget constraints which is the prerequisite for a sustainable long-term economic catch-up process.

\section{Conclusion}

Since the turn of the millennium the global macroeconomic context for countries in the economic catch-up process such as China has fundamentally changed. Capital inflows - both in form of FDI and portfolio investment - not only provide a source of scarce financing to realize productivity gains. The monetary policy rescue measures of the large industrial countries have also become the breeding ground of destabilizing capital inflows, which first stimulate growth and then contribute to overinvestment and painful crisis. Japan and the preAsian crisis Southeast Asian economies provide important case studies for such developments.

It has been argued that the monetary overinvestment theories by Wicksell (1898), Mises (1912) and Hayek (1929) provide an important theoretical framework to understand the role of too loose monetary policies for both the emergence of unsustainable 
overinvestment/speculation booms as well as lingering crisis after the bursting of these bubbles. Japan is an important reference case for China, because it has not only accomplished an export-led economic catch-up process including the development of liberalized financial markets. Japan also exhibits similar macroeconomic characteristics such as persistent current account surpluses, an ever-rising foreign currency denominated net foreign asset position as well as persistent and recurring appreciation expectations. From this perspective Japan is front-running China in very important regards.

Based on the Japanese experience, China is well advised not to follow a crisis-management strategy, which is based on the never-ending provision of low-cost liquidity by the central bank. Instead, capital controls should be maintained to insulate China from the global liquidity glut, which originates from the large central banks of the industrialized countries. China is large enough to realize a domestic demand-driven economic catch-up process behind capital controls by continuing to liberalize stepwise both domestic goods and financial markets. To provide a stable environment for this process and shield off speculative capital inflows (and outflows) a fixed exchange rate to dollar is recommended.

As long as this catch-up process continues, China is recommended to maintain a fixed exchange rate, as this ensures macroeconomic stability as a prerequisite for sustainable growth. A fixed exchange rate of yuan to the dollar would provide an anchor for intraregional exchange rate stability and - thereby - macroeconomic stability in East Asia. This would strengthen the international role of the yuan in East Asia, in particular if monetary policy remains comparatively tight to ensure low inflation and to forestall new speculative waves in Chinese stock and real estate markets. This could be seen as the first step for the Chinese yuan to take over the role in the East Asian monetary integration process, which the German mark took over as a core currency of the European monetary integration process.

\section{References}

Athukorola, Premachandra / Menon, Jayant (1994): Pricing to the Market Behaviour and Exchange Rate Pass-Through in Japanese Exports. Economic Journal 104, 271-281.

Bayoumi, Tamim / Collyns, Charles (2000): Post Bubble Blues. How Japan Responded to Asset Price Collapse, International Monetary Fund, Washington D.C.

Bergsten, Fred (2010): Correcting the Chinese Exchange Rate: an Action Plan. Testimony before the Committee on Ways and Means, U.S. House of Representatives, on 24 March 2010. 
Bernanke, Ben (2000): Japanese Monetary Policy: A Case of Self-Induced Paralysis?”, in: Mikitani, Ryoichi / Posen, Adam (eds.): Japan's Financial Crisis and Its Parallels to U.S. Experience, Institute for International Economics, Washington D.C., 149-166.

Borio, Claudio / Disyatat, Piti 2011: Global Imbalances and the Financial Crisis: Link or No Link? BIS Working Papers 346.

Blanchard, Olivier / Giavazzi, Francesco (2006): Rebalancing Growth in China: A ThreeHanded Approach. China \& World Economy 14, 4, 1-20.

Cull, Robert / Xu, Lixin (2003): Who Gets Credit? The Behavior of Bureaucrats and State Banks in Allocating Credit to Chinese State-owned Enterprises. Journal of Development Economics 71, 2, 533-559.

Caballero, Ricardo / Hoshi, Takeo, / Kashyap, Anil (2008): Zombie Lending and Depressed Restructuring in Japan. American Economic Review 98, 5, 1943-1977.

Cheung, Yin-Wong / Steinkamp, Sven / Westermann, Frank (2016): China’s Capital Flight: Pre- and Post-crisis Experiences. Journal of International Money and Finance, doi:10.1016/j.jimonfin.2015.12.009.

Cline, William / Williamson, John (2009): 2009 Estimates of Fundamental Equilibrium Exchange Rates. Peterson Institute for International Economics, Policy Brief 09-10.

De Grauwe, Paul / Ji, Yuemei (2013): Fiscal Implications of the ECB’s Bond Buying Program. Open Economies Review 24, 843-852.

Dooley, Michael / Folkerts-Landau, David / Garber, Peter (2004): The Revived Bretton Woods System. International Journal of Finance and Economics 9, 4, 307-313.

European Chamber (2016): Overcapacity in China: An Impediment to the Party's Reform Agenda. http://www.europeanchamber.com.cn.

Frankel, Jeffrey (2006): On the Yuan: The Choice between Adjustment under a Fixed Exchange Rate and Adjustment under a Flexible Rate. CESifo Economic Studies 52, 2, 246-275.

Friedman, Benjamin (2000): The Nature of the Japanese Financial Crisis. In: Mikitani, Ryoichi / Posen, Adam (eds.), Japan's Financial Crisis and Its Parallels to U.S. Experience, Institute for International Economics, Washington D.C., 27-36.

Fukumoto, Tomoyuki / Muto, Ichiro (2012): Rebalancing China’s Economic Growth: Some Insights from Japan’s Experience. China \& World Economy 20, 1, 62-82.

Funabashi, Yoichi (1989): Managing the Dollar: From the Plaza to the Louvre, Institute of International Economics, Washington D.C.

Goyal, Rishi / McKinnon, Ronald (2003): Japan's Negative Risk Premium in Interest Rates: The Liquidity Trap and the Fall in Bank Lending. The World Economy 26, 3, 339-363. 
Hamada, Koichi / Horiuchi, Akiyoshi (1987): The Political Economy of the Financial Market. In: Yamamura, Kozo / Yasuba, Yasukichi (eds.): The Political Economy of Japan, Vol. 1 The Transformation, Stanford University Press, Stanford, 223-260.

Hayek, Friedrich August von (1929): Geldtheorie und Konjunkturtheorie, Salzburg, Philosophia Verlag, Reprint 1976.

Hayek, Friedrich August von (1944): The Road to Serfdom, Routledge, London.

Hoffmann, Andreas / Schnabl, Gunther (2016): The Adverse Effects of Ultra-Loose Monetary Policies on Investment, Growth and Income Distribution. CESifo Working Paper 5754.

Huang, Haizhou / Wang, Shuilin (2004): Exchange Rate Regimes: China's Experience and Choices. China Economic Review 15, 3, 336-342.

Huang, Jikun / Rozelle, Scott (1996): Technological Change: Rediscovering the Engine of Productivity Growth in China's Rural Economy. Journal of Development Economics 49, 2, 337-369.

Jordà, Òscar / Schularick, Moritz / Taylor, Alan (2015): Leveraged Bubbles. Journal of Monetary Economics 76, S, 1-20.

Keynes, John Maynard (1936): The General Theory of Employment, Interest, and Money, Cambridge, Macmillan Cambridge University Press.

Koo, Richard (2003): Balance Sheet Recession: Japan's Struggle with Uncharted Economics and its Global Implications, Wiley and Sons.

Eggertsson, Gauti / Krugman, Paul (2012): Debt, Deleveraging, and the Liquidity Trap: a Fisher-Minsky-Koo Approach. Quarterly Journal of Economics 127, 3, 1469-1513.

Lerbs, Oliver (2015): Is China's Real Estate Market a Risk to the Global Economy? - "China's Housing Market Is Plagued by Massive Overcapacities". ZEW News, Mannheim.

Mann, Cathrine (1986): Prices, Profit Margins, and Exchange Rates. Federal Reserve Bulletin 72, 6, 366-379.

McKinnon, Ronald / Ohno, Kenichi (1997): Dollar and Yen: Resolving Economic Conflict between the United States and Japan. MIT Press, Cambridge, Massachusetts.

McKinnon, Ronald / Schnabl, Gunther (2004): The Return to Soft Dollar Pegging in East Asia? Mitigating Conflicted Virtue. International Finance 7, 2, 169-201.

McKinnon, Ronald / Schnabl, Gunther (2006): China's Exchange Rate and International Adjustment in Wages, Prices, and Interest Rates: Japan Déjà Vu? CESifo Studies 52, 2, 276-303.

McKinnon, Ronald / Schnabl, Gunther (2009): The Case for Stabilizing China's Exchange Rate: Setting the Stage for Fiscal Expansion. China \& World Economy 17, 1, 1-32. 
McKinnon, Ronald / Schnabl, Gunther (2012): China and its Dollar Exchange Rate. A Worldwide Stabilizing Influence? The World Economy 35, 6, 667-693.

McKinnon, Ronald / Schnabl, Gunther (2014): China's Exchange Rate and Financial Repression: The Conflicted Emergence of the Renminbi as an International Currency. China \& World Economy 22, 3, 1-34.

Mundell, Robert (1963): Capital Mobility and Stabilization Policy Under Fixed and Flexible Exchange Rates. Canadian Journal of Economics and Political Science 29, 479-485.

Meade, James (1951): The Balance of Payments, London.

Mises, Ludwig von (1912): Die Theorie des Geldes und der Umlaufmittel, Duncker und Humblot, Leipzig.

Löffler, Axel / Schnabl, Gunther / Schobert, Franziska (2013): Limits of Monetary Policy Autonomy and Exchange Rate Flexibility in East Asia. Working Papers on Global Financial Markets 48.

Ma, Guonan / Roberts, Ivan / Kelly, Gerard (2016): A Rebalancing Chinese Economy: Challenges and International Implications. Mimeo.

Mussa, Michael (1981): The Role of Official Intervention, Group of Thirty 6.

Quian, Yingyi / Xu, Chenggang (1998): Innovation and Bureaucracy under Soft and Hard Budget Constraints. Review of Economic Studies 65, 1, 151-164.

Peek, Joe / Rosengren, Eric (2005): Unnatural Selection: Perverse Incentives and the Misallocation of Credit in Japan. American Economic Review 95, 4, 1144-1166.

Posen, Adam (2000): The Political Economy of Deflationary Monetary Policy. In: Mikitani, Ryoichi / Posen, Adam (eds.): Japan's Financial Crisis and Its Parallels to U.S. Experience, Institute for International Economics, Washington D.C., 194-208.

Schnabl, Gunther (2015): Monetary Policy and Structural Decline: Lessons from Japan for the European Crisis. Asian Economic Papers 14, 1, 124-150.

Schnabl, Gunther / Hoffmann, Andreas (2008): Monetary Policy, Vagabonding Liquidity and Bursting Bubbles in New and Emerging Markets - An Overinvestment View. The World Economy 31, 9, 1226-1252.

Schnabl, Gunther / Spantig, Kristina (2014): (De)Stabilizing Exchange Rate Strategies in East Asian Monetary and Economic Integration. Working Papers on Global Financial Markets 53.

Schumpeter, Joseph (1912): The Theory of Economic Development, Cambridge, Massachussetts.

Sekine, Toshitaka / Kobayashi, Keiichiro / Saita, Yumi (2003): Forbearance Lending: The Case of Japanese Firms. Bank of Japan Institute for Monetary and Economic Studies 21, 2, 69-92. 
Solow, Robert (1956): A Contribution to the Theory of Economic Growth. Quarterly Journal of Economics 70, 1, 65-94.

Summers, Larry (2014): U.S. Economic Prospects: Secular Stagnation, Hysteresis, and the Zero Lower Bound. Business Economics 49, 2, 65-73.

Swan, Trevor (1956): Economic Growth and Capital Accumulation. Economic Record 32, 2, 334-361.

Taguchi, Hiroo (1994): On the Internationalization of the Japanese Yen. In: Ito, Takatoshi / Krueger, Anne (eds.): Macroeconomic Linkage: Savings, Exchange Rates, and Capital Flows, NBER-EASE Vol. 3, University of Chicago Press, Chicago, 335-357.

Takagi, Shinji (2015): Conquering the Fear of Freedom: Japanese Exchange Rate Policy since 1945. Oxford, Oxford University Press.

Ueda, Kazuo (2012): Deleveraging and Monetary Policy: Japan since the 1990s and the United States since 2007. The Journal of Economic Perspectives 26, 3, 177-201.

Wang, Yahua / Hu, Angang (2007): Multiple Forces Driving China's Economic Development: A New Analytic Framework. China \& World Economy 15, 3, 103-120.

Yoshino, Naoyuki / Kaji, Sahoko / Asonuma, Tamon (2014): Dynamic Transition of Exchange Rate Regime in China. China \& World Economy 22, 3, 36-55.

Wei, Shang-Jin / Zhang, Xiaobo (2011): The Competitive Saving Motive: Evidence from Rising Sex Ratios and Savings Rates in China. Journal of Political Economy 119, 3, 511564.

Wicksell, Knut (1898): Geldzins und Güterpreise, FinanzBuch Verlag, München. 